\title{
Tick-Borne Encephalitis Virus: A Quest for Better Vaccines against a Virus on the Rise
}

\author{
Mareike Kubinski ${ }^{1, \dagger}$, Jana Beicht ${ }^{1, \dagger}{ }^{,}$Thomas Gerlach ${ }^{1}$, Asisa Volz ${ }^{2}$, Gerd Sutter ${ }^{3}$ (D) \\ and Guus F. Rimmelzwaan $1, *$ (D) \\ 1 Research Center for Emerging Infections and Zoonoses (RIZ), University of Veterinary Medicine Hannover, \\ Foundation (TiHo), Buenteweg 17, 30559 Hannover, Germany; mareike.kubinski@tiho-hannover.de (M.K.); \\ jana.beicht@tiho-hannover.de (J.B.); thomas.gerlach@tiho-hannover.de (T.G.) \\ 2 Institute of Virology, University of Veterinary Medicine Hannover, Foundation (TiHo), Buenteweg 17, \\ 30559 Hannover, Germany; asisa.volz@tiho-hannover.de \\ 3 Institute for Infectious Diseases and Zoonoses, Ludwig-Maximilians-University (LMU) Munich, \\ Veterinaerstr. 13, 80539 Munich, Germany; gerd.sutter@lmu.de \\ * Correspondence: guus.rimmelzwaan@tiho-hannover.de \\ + These authors contributed equally to this work.
}

Received: 17 July 2020; Accepted: 10 August 2020; Published: 12 August 2020

\begin{abstract}
Tick-borne encephalitis virus (TBEV), a member of the family Flaviviridae, is one of the most important tick-transmitted viruses in Europe and Asia. Being a neurotropic virus, TBEV causes infection of the central nervous system, leading to various (permanent) neurological disorders summarized as tick-borne encephalitis (TBE). The incidence of TBE cases has increased due to the expansion of TBEV and its vectors. Since antiviral treatment is lacking, vaccination against TBEV is the most important protective measure. However, vaccination coverage is relatively low and immunogenicity of the currently available vaccines is limited, which may account for the vaccine failures that are observed. Understanding the TBEV-specific correlates of protection is of pivotal importance for developing novel and improved TBEV vaccines. For affording robust protection against infection and development of TBE, vaccines should induce both humoral and cellular immunity. In this review, the adaptive immunity induced upon TBEV infection and vaccination as well as novel approaches to produce improved TBEV vaccines are discussed.
\end{abstract}

Keywords: tick-borne encephalitis virus; TBEV; flavivirus; vaccination; vaccine; immunity; antibodies; $\mathrm{CD}^{+} \mathrm{T}$ cells; $\mathrm{CD}^{+} \mathrm{T}$ cells

\section{Tick-Borne Encephalitis Virus}

Tick-borne encephalitis virus (TBEV), a member of the family Flaviviridae and genus Flavivirus [1], is one of the most important tick-transmitted pathogens in Europe and Asia, causing annually over 10,000 clinical cases [2]. The genus Flavivirus comprises several human-pathogenic arthropod-borne viruses such as yellow fever virus (YFV), dengue virus (DENV), Japanese encephalitis virus (JEV), Zika virus (ZIKV) and West Nile virus (WNV). Since TBEV is neurotropic, it can infect the central nervous system (CNS) leading to several neurological outcomes summarized as tick-borne encephalitis (TBE) (reviewed in [3]).

Mature TBE virions are approximately $50 \mathrm{~nm}$ in diameter and have an envelope consisting of membrane (M) and envelope (E) proteins anchored in a lipid bilayer. The nucleocapsid is composed of capsid (C) proteins and the RNA genome. The non-segmented, single-stranded RNA in positive orientation has one open reading frame (ORF) coding for a single polyprotein. This protein is co- and post-translationally cleaved by viral and host proteases into three structural proteins $(\mathrm{C}$, precursor-M 
(prM), E) and seven non-structural proteins (NS1, NS2A, NS2B, NS3, NS4A, NS4B, NS5) [1,4,5]. As a viral surface glycoprotein, the E protein mediates receptor binding and membrane fusion of the viral and endosomal membrane. Moreover, it is important for inducing protective immunity [4-6]. The prM protein forms heterodimers with the E protein, thereby protecting the E protein fusion loop from premature fusion during flavivirus release [7]. In the trans-Golgi network, prM is cleaved by furin into pr and $M[8,9]$ triggering the rearrangement of E proteins on the viral surface which leads to the transition from immature to mature virions (reviewed in [10]). The non-structural proteins of TBEV play an important role in replication, processing of the polyprotein and modulation of host cell functions (reviewed in [4]). Intracellular NS1 proteins are involved in the viral RNA replication (reviewed in [6]). However, NS1 is also secreted into the extracellular space as an oligomeric "soluble antigen" [11] and contributes to a protective immune response. NS3 is the viral serine protease (with NS2B as a co-factor), RNA helicase and nucleoside triphosphatase, therefore, having a central function in viral replication and protein processing. The highly conserved NS5 protein functions as the RNA-dependent RNA polymerase and methyltransferase. NS2A, NS4A and NS4B are presumably part of the replication complex. In addition, most of the non-structural proteins of TBEV are involved in immunomodulatory processes (reviewed in [6]).

TBEV is mainly transmitted to humans and animals via tick bites (reviewed in [12]). Occasionally, alimentary transmission after consumption of raw milk or dairy products of viremic sheep, cows or goats is also possible [13-17]. Occurrence of TBEV correlates with the distribution of its vector ticks, mainly Ixodes ricinus and Ixodes persulcatus, and ranges from Europe to Siberia, Russia and Far-Eastern countries (reviewed in [18]). Phylogenetic studies based on the E protein revealed three TBEV subtypes: European (TBEV-Eu), Siberian (TBEV-Sib) and Far-Eastern (TBEV-FE). However, two potential new subtypes were described: Himalayan (TBEV-Him) and Baikalian (TBEV-Bkl) [19,20]. During the last decades, the incidence of TBE has been fluctuating annually with a general upward trend in several European countries (reviewed in [21]). Additionally, TBEV and its vectors have invaded novel regions and countries, such as the Netherlands and the United Kingdom, as well as higher altitudes observed in an Austrian alpine region $1500 \mathrm{~m}$ above sea level [16,22-26]. Possible reasons are a complex interplay of abiotic and biotic factors, combined with socio-economic circumstances and anthropogenic factors [26-28]. Furthermore, migratory birds may contribute to an expanded occurrence [24,29,30]. In general, TBEV has become an increased international health concern (reviewed in [31]). According to the Centers for Disease Control and Prevention (CDC), several TBE cases in people travelling to Europe, Russia or China were reported during 2000-2009 in the United States of America [32].

Most TBEV infections remain asymptomatic in humans. However, when symptoms occur, patients display a mono- or biphasic course with different degrees of severity depending on the causative TBEV subtype $[3,12,33]$. Mortality rates vary among the three main subtypes with an increase in fatal cases from TBEV-Eu (1-2\%) to TBEV-Sib (6-8\%) and to TBEV-FE (up to 40\%) (reviewed in [34]). In general, several factors, such as age and immune status of the infected person, infectious dose, TBEV strain and virulence, may influence the severity of the disease (reviewed in [31,35]). Approximately $75 \%$ of the symptomatic patients infected with TBEV-Eu display a typical biphasic course. The incubation period after a tick bite, with subsequent transmission of TBEV, ranges from 2-28 days (mainly between 7-14 days) [2,3,12], whereas onset of symptoms after an alimentary transmission is shorter [17]. The disease starts with non-specific symptoms, such as headache, fatigue, nausea or malaise combined with fever. This initial phase lasts for 1-8 days and reflects the viremic period. After an asymptomatic phase of 1-20 days, about one third develop a second phase involving the CNS and manifesting in e.g., meningitis, encephalitis or myelitis. Additionally, the development of long-term or permanent neurological sequelae in TBE patients has been observed [2,3,12]. During the initial (viremic) phase, TBEV RNA is present in the blood and can be detected by reverse transcriptase polymerase chain reaction (RT-PCR). However, patients are often hospitalized after the onset of neurological symptoms and at this time point, the RNA is already cleared from the blood. Thus, RT-PCR has a minor role in 
the routine diagnostics of TBEV cases. Therefore, TBEV infections are mainly confirmed serologically by the detection of TBEV-specific immunoglobulin (Ig) M and IgG (reviewed in [36]).

Currently, there are no licensed antiviral drugs against TBEV available and treatment of individual patients is supportive only (reviewed in [3]). Apart from preventive measures, such as wearing protective clothes, direct removal of ticks or avoiding consumption of unpasteurized milk (reviewed in [31]), active immunization is the most important protective measure against infection with TBEV.

\section{Currently Available Vaccines}

All licensed vaccines against TBEV are based on inactivated whole viruses, containing various strains of the European or Far-Eastern TBEV subtype (reviewed in $[34,37,38]$ ). In general, they can be grouped as European, Russian and Chinese vaccines.

Currently, two European vaccines based on the Austrian isolate Neudoerfl (FSME-IMMUN) and the German isolate K23 (Encepur), both TBEV-Eu strains, are available in many European countries and Canada $[34,39,40]$. Licensed vaccines in Russia and some neighboring countries are based on the Russian TBEV-FE isolate Sofjin (TBE vaccine Moscow and Tick-E-Vac/Klesch-E-Vac) and Far-Eastern strain 205 (EnceVir) (reviewed in [3,34]). In China, SenTaiBao based on the Chinese TBEV-FE strain Sen-Zhang is approved as a TBEV vaccine (reviewed in $[37,38]$ ). For the production of these vaccines, the respective virus isolates are grown in primary chicken embryonic cells (European and Russian vaccines) or primary hamster kidney cells (Chinese vaccine). After virus purification and inactivation, the vaccines are supplemented with an adjuvant, stabilizer and buffer/preservative (reviewed in $[3,37]$ ). In general, the vaccines differ in their antigen content and used stabilizer as shown in Table 1. Recently, an aluminum hydroxide-free, inactivated whole virus TBEV vaccine (Evervac, TBEV-FE strain Sofjin) produced in a continuous Vero cell line was tested in a phase I/II clinical trial and showed comparable safety, tolerability and immunogenicity results to the TBE vaccine Moscow. However, this vaccine is not yet licensed [41]. The vaccination schedules of the TBEV vaccines are very time-consuming. Besides the need to administer several doses for primary immunization, booster vaccinations are necessary for maintaining the protective efficacy (Table 1). Apart from the conventional schemes, rapid vaccination schedules for most of these vaccines are available (reviewed in $[3,42])$. European vaccines can be used interchangeably [43,44].

Table 1. Approved TBEV vaccines and immunization schedules.



Manufacturer: ${ }^{a}$ : Pfizer/USA, ${ }^{\text {b }}$ GlaxoSmithKline plc/United Kingdom, ${ }^{c}$ : Chumakov FSC R\&D IBP RAS/Russia,

d: Microgen-Branch FSUC "SIC "Microgen" of MOH of Russia "SIC "Virion"/Russia, e: Changchun Institute of Biological Products Co., Ltd./China. *: Germany: 50 years instead of 60 years as age limit. Abbreviations: $\mathrm{Al}(\mathrm{OH})_{3}$ : aluminum hydroxide, Eu: European, FE: Far-Eastern, HSA: human serum albumin, m: months, n.k.: not known, TBEV: tick-borne encephalitis virus, w: weeks, y: year(s).

In general, European and Russian TBEV vaccines are considered safe and well tolerated. However, mild to moderate systemic and local adverse effects, such as fever, headache or redness and swelling at the injection site, can appear both in children and adults [45-52]. 
All TBEV vaccines are highly immunogenic with high and fast seroconversion rates ranging from $86-100 \%$, depending on the TBEV vaccine, evaluation method and study design. Various studies showed seropositivity levels of 99.1-100\% for the European vaccines after complete primary immunization [49], 100\% for the Russian vaccines after two immunizations [51,52] and 86-96\% for the Chinese vaccine after two vaccinations (reviewed in $[37,53]$ ). In general, waning of the vaccine-induced immunity over time has been reported in several studies [49,54-57].

Despite the broad availability of the European vaccines, vaccine coverage in European countries is relatively low, making TBEV control difficult (reviewed in $[3,58]$ ). According to an Austrian field study, efficacy of European vaccines was calculated to be $96-99 \%$ in persons with a complete, and 91.3-92.5\% in persons with an incomplete vaccination schedule. Due to the high vaccination coverage in Austria, i.e. $85 \%$ of the population was vaccinated at least once against TBEV, and the high field effectiveness, it is assumed that approximately 4000 TBE cases were prevented during 2000-2011 [59]. In addition, the extensive vaccination of the Austrian population contributed to a strong decrease in TBE incidences in children, which was 40-times lower compared to the neighboring country Slovenia, although incidence rates were similar before [60]. Furthermore, the beneficial effect of TBEV vaccination was also demonstrated in Russia. Vaccination with TBE vaccine Moscow led to decreased incidence rates and prevention of an estimated annual 1500 novel TBE cases (reviewed in [34]). These facts highlight the importance of vaccination in preventing TBE cases.

However, immunization with TBEV vaccines does not provide complete protection. Consequently, vaccination failures and breakthrough infections can occur in patients with incomplete or even regular TBEV vaccination history. Although all age groups can be affected, breakthrough infections mostly occur in elderly persons older than 50 years of age [61-63]. TBE disease severity in patients with vaccination failure (FSME-IMMUN or Encepur) ranges from mild to severe with sometimes long-term neurological sequelae or a fatal outcome [61,63-67]. Between 2000-2015, 1.7\% of all reported TBE cases in Slovenia were breakthrough infections [63]. A further study conducted in Stockholm County (Sweden) identified that 5\% of all TBE cases between 2006-2015 occurred in vaccinated subjects [62]. However, it is assumed that the case numbers of TBEV breakthrough infections are higher [61,62].

\section{Immune Response to TBEV Infection and Vaccination}

\subsection{Innate Immunity Against TBEV}

The first defense against pathogens is the innate immune response consisting of anatomical and chemical barriers as well as innate immune cells such as natural killer cells, macrophages, neutrophils and dendritic cells. After infection, TBEV-specific pathogen-associated molecular patterns (PAMPs) are recognized by pattern recognition receptors (PRRs) of nucleated cells. Some important PRRs during infection of RNA viruses are Toll-like receptors (TLRs) 3, 7, 8 and 9 or retinoic-acid-inducible gene I (RIG-I)-like receptors. Their activation leads to the production of type I interferon (IFN) (reviewed in [68]), which was shown to have a protective role in TBEV infection (reviewed in [69]). Besides the crucial role of innate immune cells to combat TBEV, there is evidence that some of these cells are infected by TBEV, favor viral spread or contribute to pathogenesis in TBEV infection. Some non-structural proteins of TBEV, such as NS1, NS2A, NS4A, NS4B or NS5, display antagonistic functions, thus, interfering with components of the innate immune response (reviewed in [3,69-72]; [73]). In addition, TBEV infection modulates expression patterns of many antiviral genes which are involved in the innate immune response such as genes for PRRs, cytokines or chemokines [74]. Besides TBEV itself, tick-derived saliva was shown to modulate the host innate immune response by influencing pathways, such as increasing the activation of the Akt pathway in TBEV-infected dendritic cells [75], and innate immune cells (reviewed in [76]).

However, vaccination aims for the induction of adaptive immune responses and memory functions. Hence, the innate immune response will not be further discussed in this review. 


\subsection{Adaptive Immunity Against TBEV}

Virus-specific humoral and cellular immunity, mediated by neutralizing and complement-fixing antibodies as well as $\mathrm{T}$ cells with helper, cytotoxic and memory functions, are essential for protection against flavivirus infections. However, in the case of TBEV, it may also pose a risk of increased severity of infection or neuropathology [77].

\subsubsection{Antibody Response}

Antibodies induced after natural infection and vaccination play an important role as correlates of protection against TBEV since they can prevent (lethal) disease (reviewed in [3]). Antibodies can neutralize TBEV in various manners including prevention of viral attachment or fusion and support of pathogen elimination via the complement system (reviewed in [78]). Therefore, the humoral immune response is critical for controlling virus dissemination, virus clearance and long-term protective immunity (reviewed in $[79,80]$ ).

Upon TBEV infection, the amount of TBEV-specific antibodies in human serum and cerebrospinal fluid (CSF) increases and antibodies are usually detectable with the onset of neurological symptoms [2]. The highest IgM levels, which persist for around six weeks, are found in the early stages of TBE, whereas IgG levels peak in the late convalescence period [81]. IgG antibodies can persist for several years and protect from reinfection with TBEV (reviewed in [36]). In general, natural infection induces higher virus-neutralizing $(\mathrm{VN})$ antibody titers than vaccination with an inactivated virus [82]. Low serum levels of VN antibodies combined with a high number of cells (segmented granulocytes $(60-70 \%)$ and lymphocytes (30-40\%)) in the CSF at disease onset are thought to be indicative of a more severe clinical course of TBE [83].

Following primary TBEV vaccination, an increase in antibody titers is observed after the second dose which subsequently decline, followed by a strong booster response upon the third immunization [84]. Studies on long-term persistence of vaccine-induced antibodies showed durability of protective or $\mathrm{VN}$ antibodies, respectively, up to 5 years in $99 \%$ of children and above $98 \%$ in young individuals [54,56,57]. In addition, other studies reported persistence for up to 8 or even 10 years [55,85]. However, with increasing age, immunosenescence, i.e., alteration of the innate and adapted immunity, can be observed in the elderly leading to a lower immunogenicity of vaccines (reviewed in [86]). Noteworthy, avidity and functional activity of TBEV vaccine-induced antibodies are apparently neither influenced by age, age at primary immunization nor last vaccination, but are rather affected by the individual [87].

Several human linear B cell epitopes within the structural and non-structural proteins of TBEV (prM, E, NS1, NS2B, NS3, NS4B and NS5) have been identified. Two of these are located in domain I(DI) and II (DII) of the E protein, respectively, and one in the $C$-terminal RNA-dependent RNA polymerase region of NS5, and showed a positive reaction with almost all positive TBEV sera tested [88]. Intrinsic factors, such as the conformational flexibility (reviewed in [89]) and the maturation state of flaviviruses (reviewed in [90]), as well as extrinsic factors, such as the formaldehyde inactivation of virus particles during the manufacturing process of vaccines (reviewed in [39]; [88,91]), potentially impact sensitivity to antibody-mediated neutralization by changing the accessibility of epitopes. In addition, antibody avidity can be influenced by the addition of adjuvants, e.g., aluminum hydroxide, to the vaccines [92].

Upon TBEV infection and vaccination, epitopes in the E protein are the main target for the induction of $\mathrm{VN}$ antibodies (Table 2). 
Table 2. TBEV proteins eliciting TBEV-specific immune responses in humans upon TBEV infection or TBEV vaccination.

\begin{tabular}{ccc}
\hline & Infection & Vaccination \\
\hline \multirow{2}{*}{ Protective antibodies } & E [88,93] & E [88,93] \\
& NS1 [94-97] & NS1 [97] \\
\hline & C [98-100] & C [98-100] \\
CD4+ T cells & E [98-100] & E [98-100,102] \\
& NS1 [101] & \\
\hline & NS2A [103] & \\
CD8+ T cells * & NS3 [103,104] & \\
& NS4B [103] & \\
& NS5 [103]
\end{tabular}

${ }^{\dagger}$ : protective potential was shown in mouse models only [97,101,105-108]. \#: presence of NS1-specific antibodies in vaccinees still under discussion [94-97]. *: CD8+ T cell epitopes were identified for TBE patients with HLA-A2 and HLA-B7 haplotypes $[103,104]$.

On the viral surface, 180 copies of the E protein structured into 90 dimers can be found in a "herringbone-like" icosahedral arrangement (reviewed in [109]). The E monomer consists of three distinct domains (DI-DIII) connected by flexible linkers and a membrane anchor domain (DIV) (Figure 1).

A



B

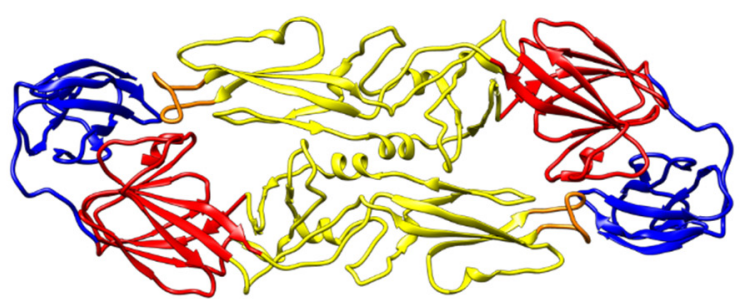

Figure 1. The structure of the TBEV E protein (PDB-ID 5O6A [5]). (A) Side view of a single TBEV E protein monomer. Depicted are the four domains (DI: red, DII: yellow, DIII: blue, DIV (stem/anchor): gray) and the fusion loop (FL: orange). (B) Top view of a soluble TBEV E protein dimer. Color code same as in (A). Ribbon diagrams were prepared with UCSF Chimera [110].

DII has an elongated finger-like structure, which is formed by two loops connecting DI, the central part of the protein, in the dimeric E protein. The hydrophobic loop at the tip of DII, covered by DI and DIII in mature virions, is responsible for the fusion of the viral and endosomal membranes, therefore, termed fusion loop (FL) [5]. The sequence of the FL is highly conserved among all flaviviruses. DIII has an immunoglobulin-like structure with exposed loops protruding from the viral surface. The structure of the E protein is influenced by the $\mathrm{pH}$ leading to increased exposure of previous inaccessible epitopes, such as the FL $[5,111]$. All three ectodomains are capable of inducing a VN antibody response (reviewed in [109,112]). Epitopes can comprise not only individual domains of the E protein but also residues from adjacent dimers and dimers in the quaternary herringbone-like arrangement of $\mathrm{E}$ proteins at the virion surface $[109,113]$. In addition, the dynamic behavior of flaviviruses, commonly known as "viral breathing", can have a great impact on antibody binding (reviewed in [89,109]).

Jarmer et al. [93] provided insights into individual specificity and the variation of the humoral immune response after TBEV infection or vaccination in humans. Using an immunoassay with recombinant $\mathrm{E}$ protein and combinations of the single E domains, they observed strong individual variation in antibody titers as well as immunodominance patterns concerning the individual $\mathrm{E}$ domains [93]. The human humoral response was dominated by EDI- and EDII-specific antibodies [88,93], 
whereas in mice immunized with inactivated, aluminum hydroxide-adjuvanted, purified TBE particles mostly EDIII-specific VN antibodies were detected [92]. Furthermore, depletion of antibodies with the dimeric E protein from sera of both naturally infected and vaccinated individuals led to a strong reduction in $\mathrm{VN}$ activity, indicating a minor role of complex quaternary epitopes in the $\mathrm{VN}$ antibody response. Additionally, depletion of EDI- and EDII-specific antibodies also significantly reduced the $\mathrm{VN}$ activity of post-infection or post-vaccination sera, suggesting that antibodies recognizing antigenic sites independent of the dimeric structure of the E protein display considerable $\mathrm{VN}$ activity [93]. The characterization of several flavivirus antibodies identified amino acids of the highly conserved FL in EDII as a dominant antigenic site for cross-reactive, but not cross-neutralizing, antibodies [114-116]. After solubilization of TBE virions with a mild detergent, EDII-specific antibodies showed a strong increase in binding avidity, indicating that the EDII-FL epitopes of native viruses may have a limited accessibility due to partial occlusion. The fact that these broadly cross-reactive, non-neutralizing antibodies are present in human sera after infection supports the hypothesis that during natural flavivirus infection, cryptic epitopes become accessible and are presented to the host immune system [116].

In addition to the E protein, the TBEV NS1 protein plays an important role as a soluble antigen. In its pentameric or hexameric form, NS1 is secreted into the extracellular space [11], inducing a NS1-specific antibody response. After natural TBEV infection, NS1-specific IgM and IgG antibodies are detectable at high levels in human sera (Table 2) [94-97]. Several studies showed that NS1 immunization or passive transfer of anti-NS1 antibodies afforded protection against infections with flaviviruses, such as DENV, YFV and WNV in animal models [117-123]. These findings have been confirmed for the TBEV NS1 protein $[97,101,105-108,124]$. Mouse studies showed that immunization with a synthetic peptide corresponding to the structurally conserved $\alpha$-helix (aa37-55) of NS1 [108] or with various synthetic fragments of NS1 [101] induced partly protective immunity against lethal challenge infection with TBEV. In addition, significantly prolonged survival of TBEV-infected mice was observed after hyperimmunization with a whole recombinant TBEV NS1 protein, although all mice succumbed to infection [97].

Whether or not an anti-NS1 immune response is induced by TBEV vaccination is matter of debate. In some studies, anti-NS1 antibodies were almost exclusively observed after natural infection but not after vaccination [94-96]. However, recent studies on the European vaccines question these findings by demonstrating the presence of NS1 in Encepur by mass spectrometry and detection of NS1-specific antibodies by Western blot in sera of vaccinees who repeatedly received Encepur or FSME-IMMUN. Moreover, vaccination with FSME-IMMUN induced a robust anti-NS1 antibody response in mice after several immunizations [97]. Further investigations are needed to confirm these results and to gain a better understanding of the role of vaccine-induced anti-NS1 antibodies. Due to the robust IgM and IgG response, NS1 might be an interesting target for novel vaccine designs and approaches.

In addition to antibodies against the E and NS1 proteins of TBEV, antibodies against the structural prM protein have been described. Analysis of sera obtained from TBE patients and vaccinees showed the presence of prM-specific antibodies, although titers were higher after infection. However, results from depletion studies indicated that prM-specific antibodies play only a minor role in TBEV neutralization [93]. In flavivirus infection, the protective potential of prM-specific antibodies has been shown e.g., for DENV in mice studies $[125,126]$. In contrast, more recent studies indicated a role of cross-reacting prM antibodies in antibody-dependent enhancement (ADE) in human DENV infection $[127,128]$. Thus, further research is required to identify which role anti-prM antibodies, induced after infection or vaccination, have in TBEV infection.

Impact of Pre-Existing TBEV-Specific Immunity

Once immunization by natural infection or vaccination has taken place, it remains an open question which role pre-existing antibodies may play in further immunizations or TBEV infection. A positive influence of pre-existing TBEV immunity on seroconversion rates following vaccination 
with Russian TBEV vaccines was observed. However, the effect disappeared 30 days after the first dose was given and after the administration of a second dose [52]. Furthermore, it has been shown that pre-existing TBEV-specific antibodies in immune complexes can have immunomodulatory effects. Immunization of mice with a soluble dimeric E protein only or together with monoclonal antibodies specific for EDI, EDII and EDIII, respectively, revealed differences in the fine specificity of the antibody response. The epitope-specific modulations of the immune response were mechanistically related to the shielding of epitopes in the E protein and the monoclonal antibody-induced dissociation of the $\mathrm{E}$ dimer, thereby revealing cryptic epitopes [129].

Due to cross-reactive epitopes, pre-existing vaccine-induced immunity mediates not only protection against homologous, but also heterologous TBEV strains. Among different TBEV subtypes, it was shown that immunization with vaccines based on TBEV-Eu or TBEV-FE elicits cross-subtype reactive antibodies [130-134]. However, studies with various TBEV vaccines showed that cross-protection against heterologous TBEV subtypes is not ensured for any strain $[134,135]$. Interestingly, one mutation in the EDI/EDII hinge region in the K23 vaccine seed virus (used for manufacturing of Encepur) was identified to be responsible for reduced VN antibody titers against heterologous Neudoerfl virus (vaccine strain used for manufacturing of FSME-IMMUN) of sera received from children vaccinated with Encepur Children. In contrast, sera of children immunized with FSME-IMMUN Junior showed comparable high levels of VN antibodies against both TBEV strains [136].

Antibodies induced by TBEV vaccination afford not only a certain degree of intra-species cross-protection but also cross-react within the TBE complex [133] and with other flaviviruses [116]. Vaccination with FSME-IMMUN or TBE vaccine Moscow protected mice against Omsk hemorrhagic fever virus (OHFV) [130,137]. Furthermore, sera of TBEV vaccinated persons could partially neutralize louping ill virus (LIV) and WNV [138]. Of interest, pre-existing vaccine-induced immunity to YFV prior to TBEV vaccination resulted in an impaired TBEV-specific VN antibody response. Nevertheless, all vaccinated study subjects reached protective TBEV neutralizing antibody titers after completing the recommended TBEV vaccination schedule [84]. On the other hand, pre-existing vaccine-induced immunity to TBEV increased the initial JEV-specific neutralizing antibody response after vaccination with an inactivated JEV vaccine in humans [139]. In general, neutralizing and non-neutralizing antibodies that cross-react with various flaviviruses can be detected post infection and vaccination $[116,138,140]$. Overall, these results indicate the presence of cross-reactive epitopes among flaviviruses and the effects of pre-existing flavivirus-specific immunity should be taken into consideration when evaluating flavivirus vaccines.

\section{Antibody-Dependent Enhancement in TBEV Infection?}

Besides the potential protective effects of cross-reactive pre-existing antibodies, they may also have detrimental effects by increasing the severity of disease through ADE of TBEV infection. Non-neutralizing antibodies could promote virus entry into susceptible host cells, leading to increased infectivity. The most common mechanism of ADE involves expression of Fc receptors. Complexes of virus and sub- or non-neutralizing antibodies binding to $\mathrm{Fc} \gamma$ receptors $(\mathrm{Fc} \gamma \mathrm{R})$ on myeloid cells, such as monocytes and macrophages, increases the attachment and uptake of the virus. As a consequence, this opsonization leads to enhanced infectivity (reviewed in [141]). Haslwanter et al. [142] identified a Fc $\gamma$ R-independent mechanism based on interactions of the FL of the TBEV E protein with cellular membranes. Studies with a monoclonal antibody (A5) recognizing an epitope in the E dimer interface demonstrated that binding of A5 triggers the dissociation of E dimers, thus exposing the buried FL. As a consequence, FL-mediated attachment to the plasma membrane increases binding and uptake of the viral particle into the cell, thereby enhancing TBEV infectivity in vitro [142].

Whereas the phenomenon of ADE was extensively described and studied for DENV infection in vitro and in vivo (reviewed in $[143,144]$ ), a potential role of ADE in TBEV infections is less well investigated. Early studies showed the ability of polyclonal sera against members of the 
TBE serocomplex to enhance TBEV replication in vitro [145]. These results are in line with the in vitro observed increased infectivity of TBEV in mouse peritoneal macrophages in the presence of sub-neutralizing TBEV antibodies [146]. Interestingly, it was shown that murine TBEV hyperimmune sera as well as TBEV-specific human polyclonal sera enhanced viral replication in mouse macrophages in vitro, but protected mice from lethal TBEV challenge. Administration of the human or murine immunoglobulins in different dilutions and combined with sublethal challenging doses revealed no signs of ADE in vivo [147]. A more recent study investigating TBEV neutralization in vitro and in mice by treatment with intravenous immunoglobulins containing high amount of TBEV-specific neutralizing antibodies supports these findings since no ADE was observed by the application of cross-reactive or virus-specific antibodies at different neutralization levels [148]. In vivo investigations in mice with sub-neutralizing concentrations of a chimeric antibody against EDIII containing the constant regions of human IgGk (chFVN145), proposed as post-exposure treatment, also showed no indications of ADE for the three main TBEV subtypes [149]. Additionally, in vivo and in vitro studies addressing the potential effect of TBEV-specific immunity on ZIKV infection suggested that humoral immunity against TBEV is unlikely to contribute to enhancement of ZIKV-induced pathogenesis in humans [150]. In summary, it is not completely clear if ADE plays a role in TBEV infection but it does not seem to be a major problem. ADE has been demonstrated for TBEV in vitro but evidence in vivo is lacking.

\subsection{2. $\mathrm{CD}^{+} \mathrm{T}$ Cell Response}

Virus-specific $\mathrm{CD}^{+} \mathrm{T}$ cell responses are essential for the induction of antiviral immunity. $\mathrm{CD} 4^{+} \mathrm{T}$ cells recognize antigenic peptides of 13-25 residues presented by major histocompatibility complex (MHC) class II molecules, which are expressed on antigen-presenting cells (reviewed in [151]). Upon stimulation, they produce pro-inflammatory and antiviral cytokines which results in the recruitment and priming of other lymphoid cells. They may have cytotoxic activity against virus-infected cells and are essential for promoting virus-specific antibody responses (reviewed in [152]).

Against infections with flaviviruses, $\mathrm{CD} 4^{+} \mathrm{T}$ cells play an important role as was demonstrated e.g., for WNV and ZIKV $[153,154]$. Studies in mice showed that clearance of primary WNV infection from the $\mathrm{CNS}$ is dependent on $\mathrm{CD}^{+} \mathrm{T}$ cells [154]. Likewise, $\mathrm{CD}^{+} \mathrm{T}$ cells contribute to controlling of ZIKV infection and are pivotal for inducing ZIKV-specific antibodies [153]. For TBEV, adoptive transfer of $\mathrm{CD}^{+} \mathrm{T}$ cells to TBEV-infected severe combined immunodeficient (SCID) mice, demonstrated a protective role of these $\mathrm{T}$ lymphocytes in limiting the development of TBE and mortality [77].

Analysis of the $\mathrm{CD}^{+} \mathrm{T}$ cell response to TBEV structural proteins demonstrated that the $\mathrm{E}$ and $\mathrm{C}$ proteins, but not the $\mathrm{prM} / \mathrm{M}$ protein, were a major target in infected and vaccinated study subjects (Table 2) $[98,99]$. Correlation of protein structure and immunodominance patterns revealed that peptides corresponding to helices $\alpha 2$ and $\alpha 4$ of the $C$ protein dominated the CD4 $4^{+} \mathrm{T}$ cell response in both vaccinated and infected individuals, whereas the $\mathrm{E}$ protein-specific $\mathrm{CD} 4^{+} \mathrm{T}$ cell response was less focused on selected protein domains. Most $\mathrm{E}$ protein-specific $\mathrm{CD} 4^{+} \mathrm{T}$ cells recognized epitopes in $\beta$-sheets of EDIII as well as exposed loops protruding from the surface of the viral particle. Additionally, vaccination induced significant EDI- and EDII-specific $\mathrm{CD} 4^{+} \mathrm{T}$ cell responses, whereas $\mathrm{CD} 4^{+} \mathrm{T}$ cell responses against peptides from the stem region of $E$ were predominantly observed in TBE patients [99]. Besides the identified $\mathrm{CD} 4^{+} \mathrm{T}$ cell epitopes in the structural proteins, several predicted $\mathrm{T}$ helper cell epitopes were located in the NS1 protein of TBEV [101]. In general, individual variation in CD4 ${ }^{+} \mathrm{T}$ cell peptide specificity as well as cytokine profile was seen in TBEV naturally infected and vaccinated persons $[98,99]$. Individuals infected with other flaviviruses, like JEV, revealed a comparable $\mathrm{CD}^{+} \mathrm{T}$ cell response, also against the JEV structural proteins and NS1 [155]. Comparison of immunodominance patterns from TBEV-, ZIKV-, DENV- and YFV-specific $\mathrm{CD}^{+}{ }^{+} \mathrm{T}$ cell epitopes revealed similarities in the distribution of some epitopes. In summary, all four flaviviruses shared epitopes in the two helices $\alpha 2$ and $\alpha 4$ of the $C$ protein and in EDI and EDII, respectively, although some amino acid sequence variation was observed in the respective epitopes [156]. 
Seven days post hospitalization, an elevated number of activated $\mathrm{CD} 4^{+} \mathrm{T}$ cells with effector functions (measured by higher human leukocyte antigen- (HLA-) DR, PD-1 and perforin expression and decreased Bcl-2 expression) was observed in TBE patients compared to control samples [104]. $\mathrm{CD}^{+}{ }^{+} \mathrm{T}$ cells responding to DENV, ZIKV, WNV, JEV and YFV are characterized by the production of interferon-gamma (IFN- $\gamma$ ), interleukin-2 (IL-2) and tumor necrosis factor-alpha (TNF- $\alpha$ ), indicating a T helper (Th) 1 cell response [153,155,157-162]. This Th1 response was also observed after TBEV infection and vaccination but differed in its specificity and functionality [98-100,102].

Overall, the frequency of TBEV-specific $\mathrm{CD}^{+} \mathrm{T}$ cells was higher after vaccination than after infection [99]. Antagonistic immunomodulatory properties of viral proteins, such as NS5, during viral infection [163] and/or an enhanced $\mathrm{T}$ cell response after booster vaccinations may explain these differences. On the other hand, a more polyfunctional phenotype of $\mathrm{CD}^{+}$memory $\mathrm{T}$ cells was found in study subjects who had recovered from acute TBEV infection, compared to vaccinees. In recovered TBE patients, a triple-positive phenotype (IL-2 $\left.2^{+} \mathrm{TNF}-\alpha^{+} \mathrm{IFN}-\gamma^{+}\right)$was observed predominantly, while in vaccinated subjects a mono- or bifunctional phenotype predominated (TNF- $\alpha^{+}$or IL-2 $2^{+}$TNF- $\alpha^{+}$) [100]. Vaccination induced high levels of IL-2, TNF- $\alpha$ and CD40L expression in CD4 ${ }^{+} \mathrm{T}$ cells but the IFN- $\gamma$ response was considerably lower compared to that observed in TBE patients $[98,100]$. The $\mathrm{CD} 4^{+} \mathrm{T}$ cell response patterns were comparable after all three vaccine doses, with the highest response after the second immunization [100]. The $\mathrm{VN}$ antibody response after vaccination correlated with $\mathrm{CD} 4^{+} \mathrm{T}$ cell functions, especially with frequencies of TBEV-specific IL-2 ${ }^{+}$and TNF- $\alpha^{+}$CD4 $4^{+}$T cells $[98,99,102]$. Whether this is also the case after infection is unclear $[98,99]$.

Studies on cross-reactivity of $\mathrm{CD} 4^{+} \mathrm{T}$ cells specific for mosquito-borne flaviviruses (reviewed in [164]) indicate that e.g., JEV-specific $\mathrm{CD}^{+} \mathrm{T}$ cells can recognize other flaviviruses which may result in stronger $\mathrm{CD}^{+} \mathrm{T}$ cell responses upon secondary infection with a heterologous virus $[165,166]$. Data on cross-reactivity of TBEV-specific $\mathrm{CD} 4^{+} \mathrm{T}$ cells with other flaviviruses are lacking.

Overall, knowledge about $\mathrm{CD} 4^{+} \mathrm{T}$ cell response after infection or vaccination is limited. $\mathrm{CD} 4^{+} \mathrm{T}$ cell subpopulations are important for protection against TBEV, however, their correlation with antibody responses and their cross-reactive potential require further evaluation.

\subsection{3. $\mathrm{CD}^{+} \mathrm{T}$ Cell Response}

In addition to virus-specific antibodies and $\mathrm{CD} 4^{+} \mathrm{T}$ cells, $\mathrm{CD} 8^{+} \mathrm{T}$ cells are an important immune correlate of protection against viral infections. $\mathrm{CD} 8^{+} \mathrm{T}$ cells recognize viral peptides of about 8-10 amino acid residues that are presented by MHC class I molecules (reviewed in [151]). So far, seven TBEV $\mathrm{CD}^{+} \mathrm{T}$ cell epitopes have been identified, all located in the non-structural proteins (NS2A, NS3, NS4B and NS5; Table 2) $[103,104]$. Almost all of these epitopes are highly conserved among European, Siberian and Far-Eastern TBEV subtypes [103].

It has been shown that flavivirus-specific $\mathrm{CD}^{+} \mathrm{T}$ cells directed to conserved non-structural proteins but also to structural proteins, display cross-reactivity across various flaviviruses. It is unclear if cross-reactive $\mathrm{CD} 8^{+} \mathrm{T}$ cells can afford protection against a heterologous flavivirus or contribute to a more severe disease outcome (reviewed in [164]). Especially for DENV infections this is a matter of debate (reviewed in [167]). However, the potential role of cross-reactive TBEV-specific CD8 ${ }^{+} \mathrm{T}$ cells is largely unknown.

The peak of $\mathrm{CD}^{+} \mathrm{T}$ cell responses in the peripheral blood of acutely infected TBE patients was about seven days after hospitalization during the second, neuroinvasive stage. TBEV-induced effector cells were characterized by increased HLA-DR, PD-1, perforin and granzyme B levels in combination with decreased expression of CD127, Bcl-2 and CD27. Furthermore, most of the CD8 ${ }^{+} \mathrm{T}$ cells $(>50 \%)$ showed monofunctional properties in virus control (degranulation, cytokine or chemokine expression) 7, 21 and 90 days after hospitalization. During the course of infection, these cells maintained their monofunctionality but altered their function. The change in the functional composition was accompanied by the differentiation of TBEV-specific $\mathrm{CD} 8^{+} \mathrm{T}$ cells with a dominant Eomes $^{+} \mathrm{Ki} 67^{+} \mathrm{T}^{-}$bet $^{+}$ 
effector phenotype (peak at day seven) into Eomes ${ }^{-} \mathrm{Ki} 67^{-} \mathrm{T}^{-}$bet $^{+}$memory cells as the infection resolved (day 21 and 90) [104].

The MHC haplotype dictates the epitope and $\mathrm{T}$ cell repertoire as well as magnitude of the virus-specific $\mathrm{CD} 8^{+} \mathrm{T}$ cell response (reviewed in [151]). This was also demonstrated for TBEV by studies investigating $\mathrm{CD}^{+} \mathrm{T}$ cell responses against non-structural TBEV proteins during acute TBEV infection $[103,104]$. Depending on HLA alleles, the differentiation of effector memory $\mathrm{CD}^{+} \mathrm{T}$ cells in two distinct phenotypes was observed. One week after hospitalization, HLA-A2- and HLA-B7-restricted TBEV epitope-specific effector cells showed a common effector memory phenotype $\left(\mathrm{CD} 45 \mathrm{RA}^{-} \mathrm{CCR} 7^{-} \mathrm{CD} 27^{+} \mathrm{CD} 57^{-}\right)$. Two weeks later, mainly effector memory (CD45RA ${ }^{-} \mathrm{CCR} 7^{-} \mathrm{CD} 27^{+} \mathrm{CD} 57^{+}$; approximately $25 \%$ of the cells) and terminally differentiated effector memory RA $\left(\mathrm{CD} 45 \mathrm{RA}^{+} \mathrm{CCR} 7^{-} \mathrm{CD} 27^{+} \mathrm{CD} 57^{+}\right.$; approximately $40 \%$ of the cells) phenotypes for HLA-A2and HLA-B7-restricted cells, respectively, were found [103].

In the brain of TBE patients with a fatal disease outcome, TBEV and activated CD8 ${ }^{+} \mathrm{T}$ cells have been demonstrated [168,169]. Expression of $\alpha 4 \beta 1$ integrin (=VLA-4) on CD8 ${ }^{+} \mathrm{T}$ cells during the neuroinvasive phase of TBEV infection may indicate the migratory capacity of these cells into the CNS [103]. Since TBEV infects neurons of the CNS [169], the recruitment of CD8 ${ }^{+} \mathrm{T}$ cells may exert, in addition to beneficial effects, detrimental effects and may contribute to the pathogenesis through the killing of infected neurons and the local secretion of cytokines such as TNF- $\alpha$. This hypothesis is supported by the observation that there were no differences in the extent of virus replication in the brains of mice surviving and in those that succumbed to experimental infection [170]. Since activated TBEV-specific CD8 ${ }^{+} \mathrm{T}$ cells show upregulation of perforin and granzyme B [104] and $\mathrm{CD}^{+}$granzyme $\mathrm{B}^{+} \mathrm{T}$ cells have been found in the brain tissue of fatal TBE cases associated with neuronal damage [168], indeed they may contribute to the pathogenesis, although uncontrolled virus replication may result also in a worse outcome of disease. A correlation between infiltrated $\mathrm{CD} 8^{+} \mathrm{T}$ cells and brain damage was also described for other flaviviruses [171-173]. Other evidence for the detrimental effects of virus-specific $\mathrm{CD}^{+} \mathrm{T}$ cells stems from work with $\mathrm{CD} 8^{-} /^{-}$knockout and SCID mice. Upon infection with a neurovirulent TBEV strain, a significantly prolonged mean survival time compared to immunocompetent mice was observed. However, all mice succumbed to infection [77]. Comparable findings have been made for WNV. Infection of $\mathrm{CD} 8^{+}$-deficient $\left(\beta 2-\mathrm{m}^{-} /^{-}\right)$mice inoculated with a high virus dose resulted in a prolonged mean survival time compared to immunocompetent mice. In contrast, $\mathrm{CD}^{+}$-deficient mice inoculated with a low dose of WNV showed, despite an extended mean survival time, an enhanced mortality rate compared to wild type mice [173]. These findings indicate that during natural flavivirus infections, which are most likely of low virus dose, $\mathrm{CD} 8^{+} \mathrm{T}$ cells may exert beneficial protective effects. Of note, it has been shown that the currently used inactivated TBEV vaccines induce virus-specific $\mathrm{CD}^{+} \mathrm{T}$ cell responses inefficiently, if at all $[100,174,175]$.

In summary, $\mathrm{CD} 8^{+} \mathrm{T}$ cells are thought to contribute to protective immunity and recovery from TBEV infection. However, further research should rule out potential downsides of $\mathrm{CD} 8^{+} \mathrm{T}$ cell-mediated immunity.

\subsubsection{Vaccine Failures}

Understanding the cause of breakthrough infections is very important for improving existing vaccines and developing new ones. Although a common definition of vaccination breakthrough infection is missing, TBE patients developing disease despite being vaccinated indicate the inability of the vaccine to induce a protective immune response in any case [176]. Host-related risk factors, such as advanced age (beyond 60 years), as well as vaccine-related risk factors, such as incomplete primary immunization or delayed first booster doses, may favor vaccination breakthrough infections (reviewed in [177]). Regarding TBEV vaccination, two types of vaccination breakthrough infections have been suggested: patients with inadequate immune response and non-responders [176].

The humoral immune response upon natural infection of individuals responding to TBEV vaccination but lacking protective efficacy, differs from those of unvaccinated TBE patients. In vaccinated 
but unprotected study subjects, IgG and VN antibodies increased rapidly, but the IgM response was delayed $[61,63-67,178,179]$. However, this differential serological profile does not explain the lack of protection.

Comparison of TBEV-specific immune responses post booster vaccination in high and non-responders revealed significant differences in their antibody response. In the non-responder group, TBEV-specific geometric mean titers (GMT) of VN antibodies were below the detection limit pre-booster (6.5 GMT). A slight increase two months after booster vaccination (18.0 GMT) with a decline six months later (10.7 GMT) was observed. In contrast, high responders showed ten-fold higher VN antibody titers pre-booster (67.5 GMT) which strongly increased eight weeks after booster vaccination (139.6 GMT) and decreased slightly afterwards (101.1 GMT) [180]. Investigation of TBEV-specific IgG avidity in both groups revealed no differences, suggesting alterations in quantity rather than quality of antibodies $[63,67,179,180]$. Further studies showed a correlation of humoral and cellular immunity in both groups: low antibody titers were associated with poor antigen-specific $\mathrm{T}$ cell proliferation, whereas high antibody titers were associated with strong $\mathrm{T}$ cell proliferation. Upon TBEV antigen-restimulation, peripheral blood mononuclear cells from TBEV vaccine non-responders were characterized by low levels of IL-2 and IFN- $\gamma$ production prior and post booster vaccination, contrary to high responders with higher cytokine expression levels. Furthermore, a decrease in regulatory $\mathrm{T}$ cells was observed in the high responder group after the booster vaccination, while non-responders displayed an increase in IL-10-producing regulatory T cells. Consequently, this might disable T cell proliferation or impair B cell-induced IgG production. This increase observed in non-responders is thought to be due to the expansion of natural as well as inducible regulatory $T$ cells. On the other hand, the decrease in high responders may be explained by the expansion of TBEV-specific effector T cells, changing the overall distribution of $\mathrm{CD} 4^{+}$subpopulations. In addition, no correlation between HLA class II haplotype and vaccination failure in TBEV non-responders was found. Interestingly, TBEV vaccine non-responders were able to develop an efficient immune response upon vaccination with seasonal influenza vaccines (Inflexal V 2008/2009 and Inflexal V 2009/2010), as observed in high responders. Hence, the non-responsiveness to TBEV vaccines is supposed to be antigen-dependent at humoral levels [180].

To overcome impaired vaccine responsiveness, especially in the elderly, further research on the understanding of TBEV vaccination breakthrough infections is warranted. Optimized or novel vaccine strategies are needed to ensure sufficient protection for all risk groups.

\section{Novel Approaches and TBEV Target Antigens for the Development of Improved TBEV Vaccines}

The currently available TBEV vaccines suffer from some disadvantages as discussed above, including: (a) the time-consuming vaccination regimen and need of regular booster vaccinations for maintaining the protective efficacy, (b) reduced immunogenicity in the elderly as well as (c) vaccination breakthrough infections and non-responders (vaccine failure). Therefore, the development of improved vaccines against TBEV is desirable. An ideal TBEV vaccine should fulfill several requirements:

- Highly immunogenic in all age and risk groups, rapid and high seroconversion rates.

- Induction of long-lasting immunity without the need for booster vaccinations.

- No vaccine failures.

- Protection against all TBEV subtypes.

- Cost-effective and safe.

To fulfill these requirements, various aspects must be considered. Central to the development of improved TBEV vaccines is obtaining a better understanding of the correlates of protection and consequently identifying the targets for humoral and cellular immune responses. In addition, the vaccine platform chosen for delivery of the antigen(s) of interest can influence the nature of the induced immune response. Thereby, combining different arms of the immune system is desirable 
to induce a strong/protective and long-lasting immunity. Although various vaccine platforms and antigens were already utilized for designing novel TBEV vaccine approaches, data on safety, tolerability and efficacy in men are lacking.

\subsection{Novel TBEV Vaccine Strategies Aiming at the Induction of Humoral Immunity}

The humoral arm of the adaptive immunity plays a major role in protection against TBEV. Of note, low VN antibody titers were associated with a more severe TBE outcome [83]. Thus, a vaccine should induce high affinity $\mathrm{VN}$ antibodies which prevent infection, dissemination and support viral clearance.

For TBEV it is known that VN antibodies are mainly directed to epitopes located in the $\mathrm{E}$ protein (Table 2). However, immunization with various soluble forms of dimeric whole or membrane anchor-free TBEV E protein failed to induce $\mathrm{VN}$ antibodies and provide appropriate immunogenicity in mice [181]. Likewise, DNA vaccines driving intracellular expression of either whole or truncated TBEV E proteins or secretion of TBEV E dimers, failed to induce VN antibodies and afford robust protection against TBEV [182]. Thus, the usage of TBEV E protein only was not very successful. In addition, flavivirus subunit vaccines based on a single protein domain of the E protein, namely EDIII, were tested. EDIII is a biologically relevant and flavivirus-specific target, inducing antibodies that are less cross-reactive than those directed against epitopes in EDI/EDII, thus, reducing a possible risk of ADE $[115,144,183]$. Immunization of mice with an attenuated recombinant influenza A virus (rIAV) encoding the WNV EDIII protein domain in frame with the IAV neuraminidase protein, induced $\mathrm{VN}$ antibodies and $\mathrm{CD}^{+}{ }^{+} \mathrm{T}$ cells as well as protection against lethal WNV challenge [184]. Contrary, immunization of mice with EDIII of ZIKV expressed from a plasmid, replication-deficient chimpanzee adenovirus or given as a recombinant protein confirmed that EDIII of ZIKV induced VN antibody responses inefficiently [185]. However, results from mouse studies need to be evaluated carefully since TBEV immunodominant regions were shown to differ in humans (EDI and EDII) [93] and mice (EDIII) [92]. Since EDIII seems to play a minor role in eliciting VN antibodies upon TBEV infection in humans [93], it is unclear whether EDIII would be a promising target for novel TBEV vaccines.

In addition to vaccine candidates based on the TBEV E protein only, those based on the $\mathrm{E}$ and prM proteins have been tested extensively. Co-expression of $\mathrm{E}$ and prM results in the self-assembly of protein complexes without a genome, known as virus-like particles (VLPs). Thus, VLPs are unable to replicate and their use is considered to be safe (reviewed in [186]). In vitro expression of prM and $\mathrm{E}$ in a VLP expression system based on mammalian cell lines [187,188] or the yeast Pichia pastoris [189], resulted in the production of such recombinant TBEV VLPs. These VLPs were smaller than native whole virions but showed similar surface protein organization (including antigenic structures) and functional reactivity (rearrangement and fusion at low $\mathrm{pH}$, hemagglutination activity) when compared to native virus particles [190]. Due to their authentic morphology, which mimic native virus particles, VLPs are highly immunogenic and able to provoke humoral as well as cellular immune responses (reviewed in $[186,191])$. Immunization of mice with purified VLPs produced in mammalian cells led to a VN antibody response and complete protection against TBEV challenge. However, immunogenicity and protective efficacy were similar to formalin-inactivated whole TBE viruses [181]. Thus, improvements to achieve a stronger immunogenicity, superior to that after vaccination with inactivated whole viruses, is desirable. One opportunity might be the incorporation of $C$ proteins in the VLPs as demonstrated for ZIKV VLPs. Direct comparison of recombinant ZIKV VLPs without (prM-E) and with C (C-prM-E), both produced in a stable cell line, showed that in mice immunized with C-prM-E VLPs neutralizing antibody titers were enhanced, C-specific antibodies were detectable and viremia upon challenge infection was prevented [192]. In addition to recombinant VLPs produced in vitro, they can also be produced in situ after vaccination with nucleic acid-based vaccines or live attenuated viruses encoding the prM and E proteins (Figure 2). 


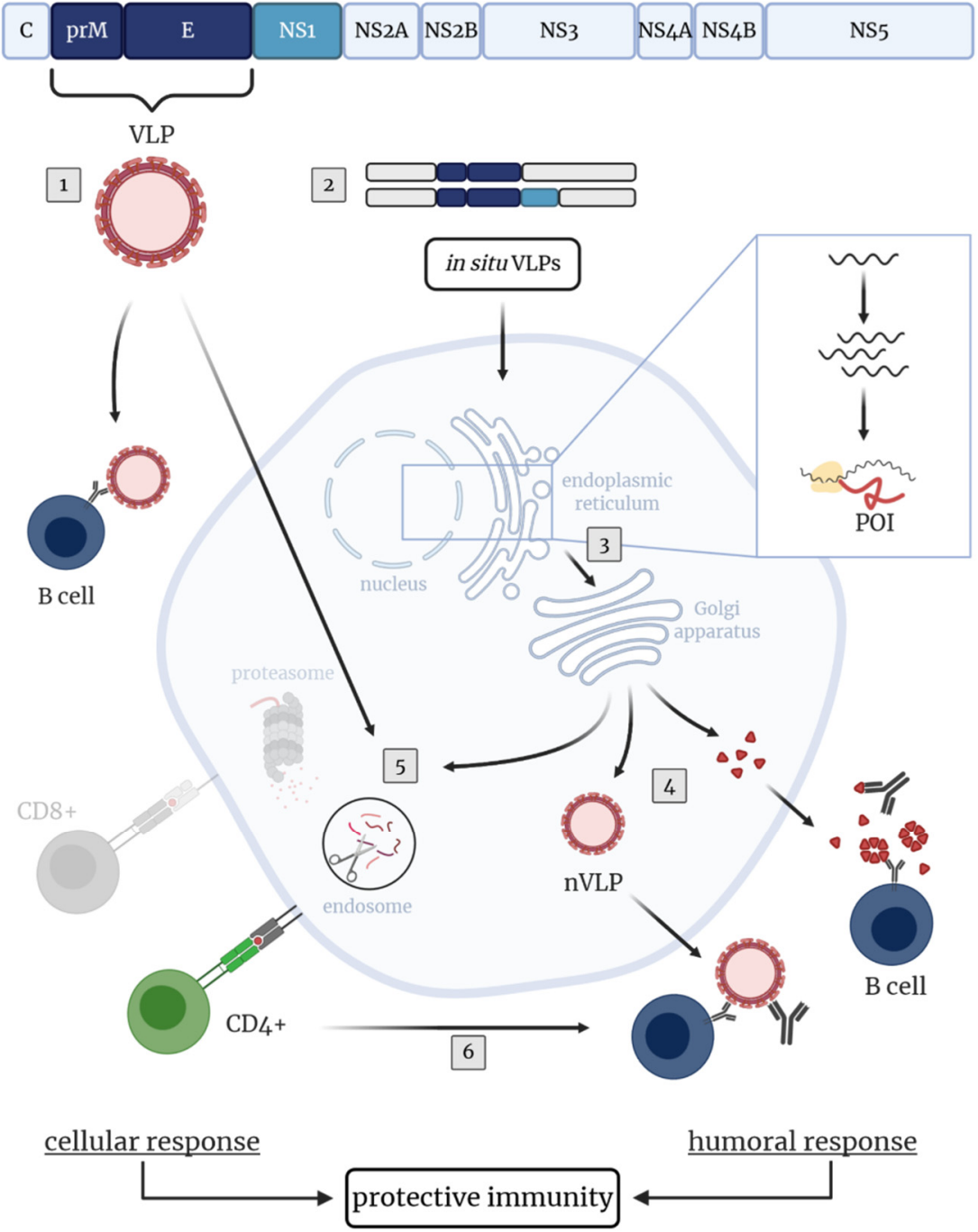

Figure 2. TBEV-specific immunity upon immunization with virus-like particles (VLPs). The TBEV polyprotein with proteins inducing protective antibody responses (prM, E, NS1) is shown. Upon immunization with purified VLPs (1) or vector-based vaccines co-expressing prM and E (in situ production of VLPs, (2)), mainly humoral immune responses are induced. Inclusion of the NS1 protein in these vector-based vaccine approaches may improve the protective immunity. (3) Vector-based immunization leads to the synthesis of proteins of interest (POIs), which are processed on different pathways leading to humoral and/or cellular immune responses. (4) Humoral immune response: POIs are either secreted into the extracellular space (NS1) or assemble into novel VLPs (nVLPs; prM-E) which are subsequently released from the cell. The secreted proteins and de novo produced (nVLPs) or directly administered VLPs, respectively, induce the production of TBEV-specific B cells and antibodies. (5) Cellular immune response: The POIs or endocytosed VLPs, respectively, are degraded into peptides mainly by host proteases in endosomes leading to antigen presentation via MHC class II molecules to $\mathrm{CD}^{+} \mathrm{T}$ cells. (6) $\mathrm{CD} 4^{+} \mathrm{T}$ cells promote the activation and proliferation of TBEV-specific B cells driving efficient antibody responses with development of memory responses. Created with BioRender.com.

Immunization with a DNA-based vaccine enabling assembly of recombinant TBEV VLPs in vivo, elicited the production of VN antibodies in mice [182,193] and rhesus macaques [194]. Additionally, immunized mice or mice treated with serum of vaccinated non-human primates were protected against TBEV challenge $[182,193,194]$. Moreover, in situ generation of TBEV VLPs by vaccination of mice with a late-defective recombinant Vaccinia virus (rVACV) encoding for the prM and E proteins, induced $\mathrm{VN}$ antibodies and a robust protection upon challenge infection with TBEV [195]. Altogether, these 
data suggest that co-expressed prM and $\mathrm{E}$ induced superior immune responses with higher protective efficacy than the E protein alone. Therefore, strategies including prM and E should be pursued in further research.

Besides VN antibodies against the E protein, anti-NS1 antibodies were detectable in sera of TBE patients [94-97]. Mouse studies showed that these antibodies afforded partial protection from TBEV infection $[97,101,108]$. Therefore, the NS1 protein may be considered a promising additional vaccine target in future TBEV vaccines. Immunization with a replication-defective recombinant adenovirus (rAd) encoding the NS1 protein of TBEV elicited NS1-specific antibodies in mice, prevented viremia and afforded partial protection [106,107]. The NS1-induced protective immunity is mediated mainly by antibodies and B cells as was demonstrated by adoptive transfer experiments [196]. Similar results were obtained with rVACV encoding for TBEV NS1, which afforded partial protection against TBEV challenge infection [197]. Although NS1-based TBEV vaccine preparations may not be suitable as stand-alone vaccines, its addition to vaccines might increase their efficacy. Studies with an attenuated recombinant vesicular stomatitis virus (rVSV) encoding for a polyprotein consisting of ZIKV prM, $E$ and NS1 support this idea. Immunization of mice with this live attenuated vaccine candidate elicited high levels of VN antibodies, cellular immunity and complete protection against ZIKV challenge infection [198]. Although, evidence for ADE of TBEV in vivo is lacking, the potential risk of enhanced infectivity should be taken into consideration when developing novel vaccines. Thus, the use of the NS1 protein as vaccine antigen might be of interest since it can contribute to protective immunity with a presumably low risk of $\mathrm{ADE}$, which could be an issue for the E protein.

As shown for some of the licensed TBEV vaccines [130-135], ideally novel TBEV vaccines should induce cross-protective immunity to other TBEV subtypes. This has been achieved with vaccine candidates containing the prM-E or NS1 protein. Gene Gun immunization of mice with infectious TBEV RNA carrying a large deletion in the $3^{\prime}$ non-coding region (NCR), which allowed attenuated replication and expression of all viral proteins, afforded protection against a lethal dose of a heterologous TBEV strain [199]. Additionally, protection against heterologous TBEV strains in mice was achieved by transfer of serum obtained from non-human primates immunized with a TBEV prM-E DNA vaccine [194]. Moreover, the cross-protective potential against heterologous TBEV subtypes as well as against OHFV, another member of the Flaviviridae family, was demonstrated in mice with a rAd encoding NS1 of TBEV [196]. Likewise, cross-protective antibodies against Langat virus (LGTV), a flavivirus closely related to TBEV (reviewed in [200]), were induced in mice after immunization with plasmid DNA encoding the TBEV prM and E proteins [193]. Interestingly, a modified lipid nanoparticle-mRNA vaccine encoding prM and E of Powassan virus (POWV), a member of the TBE serocomplex, induced antibodies that cross-reacted with TBEV and LGTV and protected mice from LGTV challenge infection, despite these three flaviviruses displaying only $77 \%$ amino acid identity in the E protein [201].

To summarize, data on TBEV or other flavivirus vaccine candidates based on various vaccine platforms and proteins demonstrated their potential in eliciting VN antibodies and affording protection against challenge infections. Due to the importance of $\mathrm{VN}$ antibodies in protective immunity to TBEV, their induction by future vaccines is a must. To our knowledge, none of the vaccine candidates described above have reached clinical trials yet. Thus, data on immunogenicity and protective efficacy rely on pre-clinical studies and must be confirmed clinically.

The decline of TBEV-specific antibody titers necessitates regular booster vaccinations (Table 1) to maintain protection afforded by the licensed vaccines [49,54-57], which sometimes fail to provide protection, especially in the elderly [61-67]. The induction of robust cellular immunity by novel vaccine candidates may help to prevent these problems and potentiate protective efficacy.

\subsection{Novel TBEV Vaccine Approaches Aiming at the Induction of Cellular Immunity}

Various novel TBEV vaccine candidates have been tested for their capacity to enhance immunity by induction of virus-specific $\mathrm{T}$ cell responses. The importance of virus-specific $\mathrm{T}$ cells in protective 
immunity to TBEV infection has been demonstrated by adoptive transfer experiments to naïve recipient mice [77]. In humans, the VN antibody levels induced after vaccination correlated with $\mathrm{CD}^{+} \mathrm{T}$ cell functionality $[98,99,102]$. For the induction of long-lasting protective immunity, quantity but also quality of $\mathrm{CD}^{+} \mathrm{T}$ cells are of importance since these $\mathrm{T}$ lymphocytes regulate $\mathrm{B}$ cell responses and antibody production. On the one hand, follicular helper $\mathrm{T}$ (Tfh) cells are necessary to produce high affinity antibodies and on the other hand, $\mathrm{CD}^{+} \mathrm{T}$ cells contribute to protective immunity by e.g., differentiation into cytokine-producing polyfunctional cells (Th1 response) and establishment of an immunological memory (reviewed in [202,203]). TBEV CD4 ${ }^{+} \mathrm{T}$ cell epitopes (Table 2) were identified within the E and C proteins [98,99]. Predictions suggested the presence of epitopes in the TBEV NS1 protein [101]. Comparable immunodominant epitopes in E and C were identified for ZIKV, DENV, YFV and JEV [155,156]. T cells directed to these epitopes might display cross-reactivity. Thus, TBEV vaccines may induce a certain degree of cross-reactive immunity to other flaviviruses.

With live attenuated rIAV and modified Vaccinia virus Ankara (rMVA) as WNV vaccine candidates, WNV EDIII and E protein specific CD4 ${ }^{+}$T cell responses, respectively, could be induced [184,204]. Also the use of flavivirus VLPs led to the induction of virus-specific $\mathrm{CD}^{+} \mathrm{T}$ cell responses, as was shown for ZIKV VLPs $[205,206]$. Comparison of mouse CD4 ${ }^{+}$T cell responses induced with rVSV encoding the ZIKV prM-E alone or together with the NS1 protein showed that co-expression of NS1 increased CD4 ${ }^{+} \mathrm{IFN}-\gamma^{+}$T cell responses and decreased CD4 $4^{+} \mathrm{TNF}-\alpha^{+}$Th1 cells [198]. This underlines that NS1 has apparently immune modulatory properties and can alter the nature of the T cell response.

Besides the used proteins, the antigen delivery system and the route of administration can have a major impact on vaccination outcome. For example, comparison of intramuscular vaccination of mice with DNA (TBEV prM-E) induced a Th1 response (more IgG2a than IgG1 antibodies, dominant IFN- $\gamma$ response), whereas Gene Gun immunization provoked a Th2 response (more IgG1 than IgG2a antibodies, dominant IL-4 and IL-5 response) [182]. Furthermore, the magnitude of the VN antibody response was influenced by the application method of another DNA-based vaccine (TBEV prM-E). Mice immunized intramuscularly by a needle-free jet injector developed a greater VN antibody response than after subcutaneous vaccination with needle-syringe injection, albeit lower amounts of DNA were used for needle-free immunization. The wide dispersion and therefore enhanced uptake of DNA after needle-free administration most likely account for this difference [207]. Using nucleic-acid vaccines, the biochemical delivery method and use of adjuvants influence vaccine-induced immunity, too (reviewed in [208,209]). With the use of adjuvants, immune responses can be biased, like in the case of MF59, to enhanced Tfh and germinal B cell responses [210].

Since virus-specific $\mathrm{CD}^{+} \mathrm{T}$ cells also contribute to protective immunity against virus infections, proteins with $\mathrm{CD}^{+} \mathrm{T}$ cell epitopes are considered as vaccine targets. For TBEV, $\mathrm{CD} 8^{+} \mathrm{T}$ cell epitopes in the non-structural proteins NS2A, NS3, NS4B and NS5 have been identified [103,104]. Immunization of mice with a rVACV expressing TBEV C-prM-E-NS1-NS2A-NS2B-NS3 (vC-NS3) demonstrated that including non-structural proteins, which contain $\mathrm{CD}^{+} \mathrm{T}$ cell epitopes, increased the protective efficacy of this vaccine preparation (Figure 3). Immunization with vC-NS3 induced superior TBEV-specific antibody levels, limited viral load most efficiently and provided the highest level of protection compared to immunization with rVACV encoding C-prM-E-NS1 or 5'NCR-C-prM-E-NS1-NS2A of TBEV only [211].

Upon vaccination with live viruses, antigens are synthesized in the cytoplasm of infected cells which facilitates endogenous antigen processing and subsequent MHC class I-restricted presentation of viral peptides. Consequently, the induction of virus-specific $\mathrm{CD} 8^{+} \mathrm{T}$ cell responses are facilitated. For example, WNV antigen-specific (memory) $\mathrm{CD}^{+} \mathrm{T}$ cell responses were promoted in mice with a rMVA-WNV vaccine candidate [204]. In contrast, inactivated vaccines, like the licensed TBEV vaccines, induce $\mathrm{CD}^{+} \mathrm{T}$ cells inefficiently $[100,174,175,212]$. One of the most effective and safest vaccines used in humans is the live attenuated YFV 17D vaccine. This vaccine induces VN antibodies and T cell responses which provide long-term protective immunity against Yellow Fever after a single dose 
(reviewed in [213]). Such a durable vaccine-induced immunity is desirable since repeated vaccinations are not required.

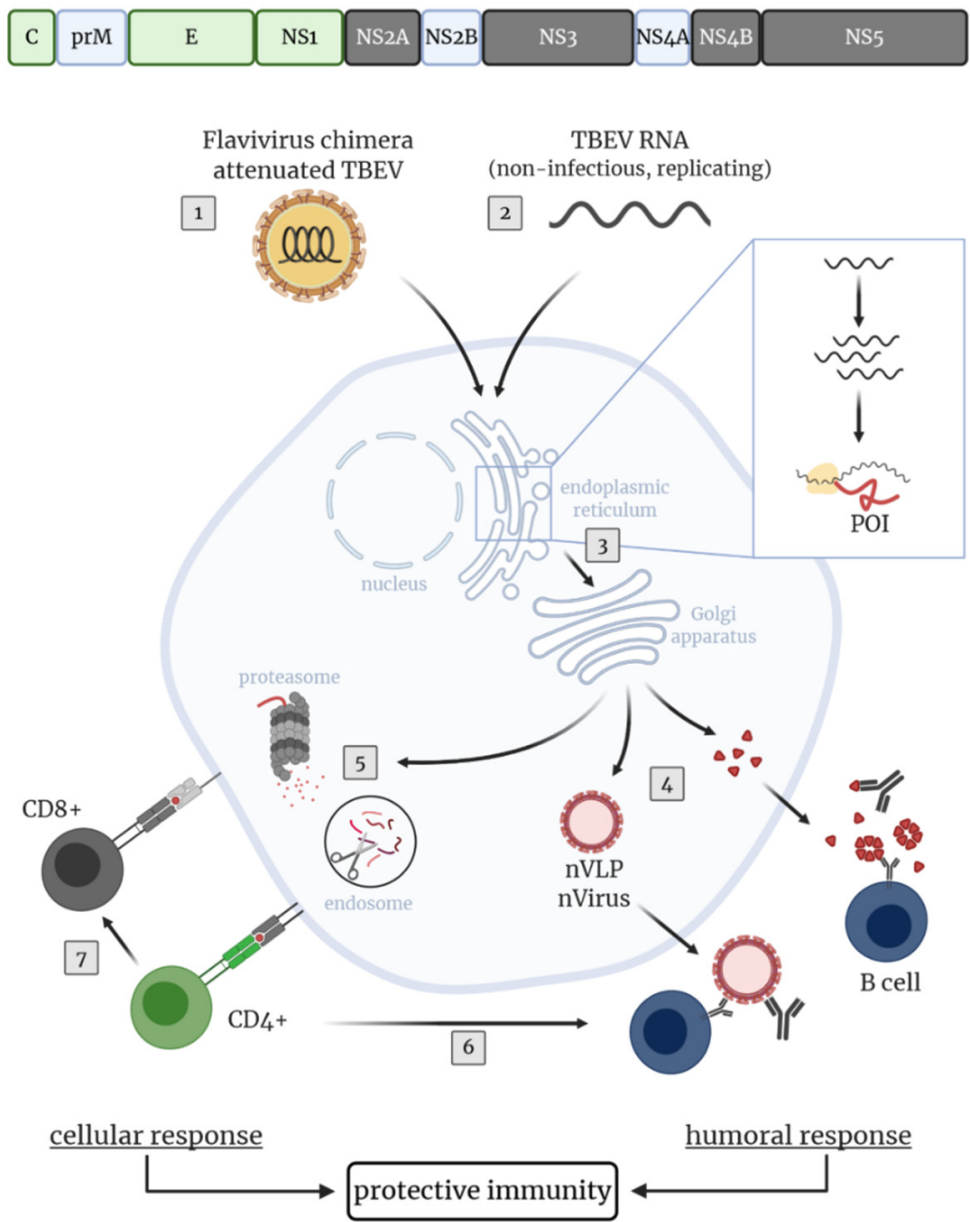

Figure 3. Inclusion of flavivirus non-structural proteins to enhance vaccine-induced immunity. The TBEV polyprotein with proteins inducing $\mathrm{CD}^{+}(\mathrm{C}, \mathrm{E}, \mathrm{NS1})$ and $\mathrm{CD} 8^{+}$(NS2A, NS3, NS4B, NS5) T cell responses is shown. Upon immunization with live attenuated flaviviruses (1) or non-infectious, replicating TBEV RNA (2), structural as well as non-structural proteins are included, promoting a humoral but also an efficient cellular immunity. (3) Immunization leads to the synthesis of proteins of interest (POIs), which are processed on different pathways leading to humoral and/or cellular immune responses. (4) Humoral immune response: POIs are either secreted into the extracellular space (NS1) or assemble into novel VLPs (nVLPs) or virions (nVirus) which are subsequently released from the cell. Thus, TBEV-specific B cells and antibodies are induced. (5) Cellular immune response: The POIs are degraded into peptides either by host proteases in endosomes or by proteasomes in the cytoplasm. By this process antigens are presented via MHC class II or I molecules to CD4 ${ }^{+}$or CD8 ${ }^{+} \mathrm{T}$ cells. $\mathrm{CD} 4^{+}$ $\mathrm{T}$ cells promote the activation and proliferation of TBEV-specific B cells (6) and CD8 ${ }^{+} \mathrm{T}$ cells (7) with the development of memory responses. Created with BioRender.com.

For TBEV, a live virus vaccine based on an attenuated LGTV strain was evaluated in Russia by the immunization of approximately 650,000 volunteers. A single vaccination led to $100 \%$ seroconversion in all vaccinees and antibodies persisted for several years. However, this LGTV-based vaccine proved not to be safe and caused a relatively high incidence of encephalitis. Furthermore, the vaccine failed to afford complete protection against TBEV, probably because of limited antigenic cross-reactivity between LGTV and local TBEV strains (reviewed in [200]). Although these first attempts to use LGTV as a live virus vaccine against TBEV were overshadowed by severe neurological adverse events, further investigations were undertaken to develop safe, attenuated TBEV vaccine strains that mimic TBEV 
infection upon vaccination. Deletions or introduction of several mutations in the $3^{\prime} \mathrm{NCR}, \mathrm{C}, \mathrm{E}$ or NS5 proteins were identified to contribute to an attenuated TBEV phenotype [199,214-220]. These approaches opened new opportunities for producing attenuated live virus vaccines that allow the induction of antibody and $\mathrm{T}$ cell responses to both structural and non-structural TBEV proteins. Subsequent studies in mice showed that such attenuated TBE viruses provided protection against challenge infection with wild type TBEV [214,216-220]. However, to our knowledge none of these candidates have been further evaluated in detail or tested in clinical trials, likely due to safety concerns.

Further studies investigated live attenuated chimeric flaviviruses for their capacity to induce protective immunity with a safe profile. Currently, two live chimeric flavivirus vaccines, the tetravalent vaccine Dengvaxia against DENV (reviewed in [221]) and IMOJEV against JEV (reviewed in [222]), based on the attenuated YFV 17D backbone are licensed for use in humans. For TBEV, flavivirus chimera based on various backbones derived from YFV 17D, attenuated JEV, DENV-2, DENV-4, LGTV and the WNV RepliVax platform, have been designed by replacing the prM and E genes of the respective virus vector with those of TBEV or LGTV [223-232]. Although, TBEV-specific antibodies and protective immunity were induced, for several of those chimeric viruses neurovirulence constituted a safety issue $[223,224,233,234]$. On the other hand, promising results regarding safety and protective efficacy were obtained in mice and non-human primates with the RepliVax WNV/TBEV [223], a microRNA-targeted TBEV/LGTV [231] and a LGTV/DENV-4 chimera [227,233,235,236]. Interestingly, a single dose of the microRNA-targeted TBEV/LGTV vaccine candidate induced VN antibody titers in non-human primates comparable to those after three doses of Encepur [231]. The chimeric LGTV/DENV-4 vaccine candidate, however, induced VN-cross-reactive TBEV-specific antibodies inefficiently in human study subjects. Booster vaccination failed to enhance the cross-reactive TBEV-specific antibody levels [237]. Collectively, these studies highlight the difficulties finding the optimal balance between immunogenicity and attenuation/safety of chimeric viruses. Moreover, vaccines based on chimeric flaviviruses are dependent on cross-reactive $\mathrm{T}$ cells between the chosen flavivirus backbone and TBEV, since TBEV-specific T cell epitopes are mainly located in the C and non-structural proteins which are encoded by the backbone of the vaccine. Of note, it was recently shown that $\mathrm{CD}^{+}$and $\mathrm{CD}{ }^{+} \mathrm{T}$ cells induced by the YFV 17D vaccine exhibited limited cross-reactivity with other mosquito-borne flaviviruses as well as lower antigen-sensitivity against heterologous antigens [238]. These findings might suggest that with e.g., TBEV/YFV 17D chimera as a novel vaccine candidate, inadequate TBEV-specific T cell responses could be evoked. Therefore, the protective efficacy of cross-reactive $B$ and $T$ cell responses to TBEV have to be addressed in further studies.

To include TBEV non-structural genes in the vaccine formulation and circumvent safety issues of live attenuated virus vector vaccines, a replication-competent, non-infectious TBEV RNA was generated. By introducing an in-frame deletion of approximately two-thirds of the $\mathrm{C}$ protein, production of infectious virions was prevented, whereas point mutations in the prM signaling sequence promoted efficient release of subviral particles [174,239]. Upon immunization, TBEV-specific VN antibodies, Th1 and $\mathrm{CD}^{+} \mathrm{T}$ cell responses were induced, quantitatively and qualitatively comparable to those induced by vaccination with a live attenuated virus. Pre-existing immunity to TBEV seemed to not have negative effects because humoral and $\mathrm{CD}^{+} \mathrm{T}$ cell responses increased after booster immunization [174]. Of interest, the virus harboring the deletion in the $C$ protein only and lacking the point mutations in the prM signaling sequence, failed to induce VN antibody titers. Nevertheless, all mice were protected against lethal TBEV challenge infection [239]. This highlights that cellular mediated immunity is an important correlate of protection and supports the notion that inducing $\mathrm{T}$ cell responses to non-structural proteins should be considered a favorable property of future TBEV vaccine formulations.

For the use of viral vectors, interference by pre-existing vector immunity is considered a potential disadvantage (reviewed in [240]). The use of heterologous prime-boost vaccination schemes may overcome this problem and evoke durable memory $\mathrm{T}$ cell responses (reviewed in [241]). By priming e.g., with a DNA vaccine, especially the cellular immune response to the antigen of interest can be increased upon booster vaccination with a vaccine of another nature (reviewed [242]), like viral 
vectors based on poxviruses [243] or adenoviruses [244,245]. These favorable vaccination outcomes have been demonstrated in mouse studies using TBEV NS1-encoding rVACV for priming and TBEV NS1-encoding plasmid DNA for boosting. This heterologous prime-boost strategy provided protective immunity against lethal TBEV challenge infection, whereas several repeated vaccinations were needed with each of the individual vaccine preparations to achieve this [246].

\section{Conclusions and Future Perspectives}

Over the last few years, TBEV has become a major health concern due to the increased spread of TBEV endemic foci and ticks, as well as rise in TBE incidences (reviewed in [21]). The most efficient protective measure against TBE is vaccination. Despite the good tolerability, safety and field efficacy of currently available inactivated TBEV vaccines, they exhibit some shortcomings, such as the need for time-consuming vaccination schedules or incomplete protection, especially in the elderly. Novel vaccination strategies may overcome some of the limitations of the licensed TBEV vaccines. For the development of novel vaccines, thorough understanding of the immune correlates of protection against TBEV is crucial and should be the subject of further investigations. Efficient induction of virus-specific memory $\mathrm{B}$ and $\mathrm{T}$ cell responses is pivotal for providing durable protective immunity and the prevention of vaccination breakthrough infections in TBEV vaccinees. In addition to long-lasting TBEV E and NS1 protein-specific protective antibodies, robust TBEV-specific cellular immune responses will contribute to favorable disease or vaccination outcomes. So far, a limited number of $\mathrm{CD} 4^{+} \mathrm{T}$ cell epitopes in the structural [98-100], and CD8 ${ }^{+} \mathrm{T}$ cell epitopes in the non-structural proteins $[103,104]$ of TBEV have been identified. However, the contribution of $\mathrm{T}$ cell responses to these individual epitopes affording a protective immunity has been under-investigated and the full repertoire of $\mathrm{T}$ cell specificities is largely unknown. Likewise, the immune response elicited by the licensed TBEV vaccines is still not fully understood.

Issues that need to be addressed include the induction of NS1-specific antibodies upon vaccination with the licensed vaccines [94-97] and the cross-reactivity of TBEV-specific T cells. So far, in vivo proof of ADE for TBEV is lacking, however, the effects of pre-existing immunity against other flaviviruses in this regard should be kept in mind when developing novel vaccine approaches.

A number of novel TBEV vaccination strategies are in various stages of development and have been tested, mainly in pre-clinical models (Table 3). Combinations of TBEV structural and non-structural antigens have been tested for their capacity to induce protective $\mathrm{VN}$ antibodies and virus-specific $\mathrm{CD} 4^{+}$ and $\mathrm{CD} 8^{+} \mathrm{T}$ cell responses. To our knowledge, a live attenuated LGTV/DENV-4 chimera has been the only novel vaccine candidate tested in a clinical trial. Although it proved to be highly attenuated and safe, cross-reactivity of the antibody response with TBEV was poor [237]. In general, most vaccination strategies mainly include the prM and E proteins of TBEV to elicit protective antibody responses. The inclusion of TBEV proteins that induce potent $\mathrm{CD} 4^{+}$and $\mathrm{CD} 8^{+} \mathrm{T}$ cell responses may improve vaccine efficacy and durability. Moreover, further testing of the NS1 protein as vaccine antigen seems warranted since it afforded partial protection in mouse models.

A better understanding of the correlates of protection against TBEV obtained in recent years combined with lessons learned from novel vaccine strategies against TBEV or other flaviviruses may pave the road for the development of improved TBEV vaccines that can be safely used in all age and risk groups and that afford solid protection from TBE. 
Table 3. In vivo evaluated approaches for TBEV vaccine candidates and their outcome.

\begin{tabular}{|c|c|c|c|c|c|c|c|c|}
\hline \multirow{2}{*}{ Approach } & \multirow{2}{*}{ Strategy } & \multirow{2}{*}{$\begin{array}{l}\text { Included TBEV } \\
\text { Target Antigens }\end{array}$} & \multicolumn{3}{|c|}{ TBEV-Specific Adaptive Immunity } & \multirow{2}{*}{$\begin{array}{c}\text { Protection } \\
\text { (Challenge Virus) }\end{array}$} & \multirow{2}{*}{ Comment } & \multirow{2}{*}{ Ref. } \\
\hline & & & Antibodies & CD4+ T Cells & CD8+ T cells & & & \\
\hline \multicolumn{9}{|c|}{ Vaccination with proteins } \\
\hline $\begin{array}{l}\text { Mammalian cell line-based } \\
\text { expression system }\end{array}$ & $\begin{array}{l}\text { Production of recombinant E protein } \\
\text { (soluble dimeric E without membrane } \\
\text { anchor) from plasmid (COS-1 cells), } \\
\text { comparison to virus-derived E dimers } \\
\text { (with//without membrane anchor) and E } \\
\text { rosettes (multimeric aggregates) } \\
\text { - Evaluated in mice }\end{array}$ & E (Dimers or rosettes) & $+(\mathrm{VN}-\mathrm{Ab})$ & n.d. & n.d. & $++/+(\mathrm{TBEV})$ & $\begin{array}{l}\text { E dimers: Very low VN-Ab } \\
\text { Low or no protection against } \\
\text { heterologous TBEV strain } \\
\text { E rosettes: } \\
\text { - } \\
\text { Higher VN-Ab titer compared to } \\
\text { E dimers } \\
\text { Complete protection against } \\
\quad \text { heterologous TBEV strain }\end{array}$ & [181] \\
\hline \multicolumn{9}{|c|}{ Virus-like particles (VLPs) } \\
\hline $\begin{array}{l}\text { Mammalian cell line-based } \\
\text { expression system }\end{array}$ & $\begin{array}{l}\text { Production of VLPs from recombinant } \\
\text { plasmid (COS-1 cells), purified VLPs } \\
\text { used for immunization } \\
\text { - Evaluated in mice }\end{array}$ & prM-E & $+(\mathrm{VN}-\mathrm{Ab})$ & n.d. & n.d. & $++(\mathrm{TBEV})$ & $\begin{array}{ll}\text { - } & \text { Protection against heterologous } \\
\text { TBEV strain } \\
\text { - Higher VN-Ab titer compared to E } \\
\text { rosettes (see above) } \\
\text { VN-Ab and protection levels } \\
\text { comparable to formalin-inactivated } \\
\text { whole virus (used as control) }\end{array}$ & [181] \\
\hline \multicolumn{9}{|c|}{ DNA vaccines } \\
\hline DNA encoding for VLPs & $\begin{array}{l}\text { In vivo production of VLPs from } \\
\text { plasmid DNA encoding prM-E } \\
\text { - Evaluated in mice and NHP }\end{array}$ & prM-E & $\begin{array}{l}+(\mathrm{VN}-\mathrm{Ab} \text { in } \\
\text { mice + NHP) }\end{array}$ & + & n.d. & ++(TBEV: mice) & 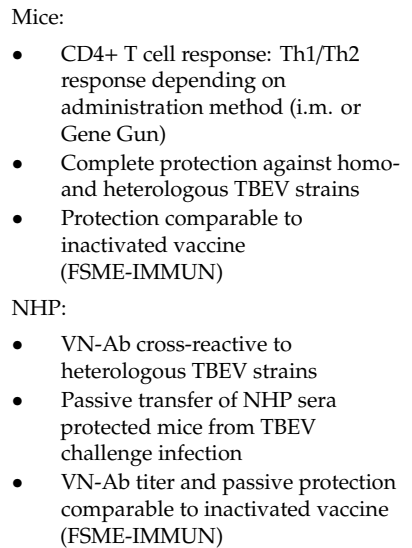 & {$[182,193,194]$} \\
\hline
\end{tabular}


Table 3. Cont.

\begin{tabular}{|c|c|c|c|c|c|c|c|c|}
\hline \multirow{2}{*}{ Approach } & \multirow{2}{*}{ Strategy } & \multirow{2}{*}{$\begin{array}{l}\text { Included TBEV } \\
\text { Target Antigens }\end{array}$} & \multicolumn{3}{|c|}{ TBEV-Specific Adaptive Immunity } & \multirow{2}{*}{$\begin{array}{c}\text { Protection } \\
\text { (Challenge Virus) }\end{array}$} & \multirow{2}{*}{ Comment } & \multirow{2}{*}{ Ref. } \\
\hline & & & Antibodies & CD4+ T Cells & CD8+ T cells & & & \\
\hline DNA encoding for E protein & $\begin{array}{l}\text { Immunization with plasmid DNA } \\
\text { encoding antigens (secreted terminally } \\
\text { truncated soluble E dimer, non-secreted } \\
\text { full-length E, inefficiently secreted } \\
\text { truncated E) } \\
\text { - Evaluated in mice }\end{array}$ & E & $+(\mathrm{VN}-\mathrm{Ab})$ & + & n.d. & $+/-(\mathrm{TBEV})$ & $\begin{array}{l}\text { - Very low VN-Ab (depending } \\
\text { on antigen) } \\
\text { CD4+ T cell response: Th1/Th2 } \\
\text { response (depending on } \\
\text { administration method (i.m. or } \\
\text { Gene Gun)), weaker compared to } \\
\text { VLPs or inactivated vaccine } \\
\text { (FSME-IMMUN) }\end{array}$ & [182] \\
\hline \multicolumn{9}{|c|}{ RNA vaccines } \\
\hline ‘Naked' infectious RNA & $\begin{array}{l}\text { Application of infectious in vitro } \\
\text { synthesized RNA of an attenuated TBEV } \\
\text { mutant (carrying a } 470 \text { nt deletion in the } \\
3^{\prime} \mathrm{NCR} \text { for attenuation), immunization } \\
\text { with purified infectious RNA leading to } \\
\text { replication of highly attenuated mutant } \\
\text { virus in vivo } \\
\text { - Evaluated in mice }\end{array}$ & Whole TBEV & + & n.d. & n.d. & ++(TBEV) & $\begin{array}{ll}\text { - Immunization afforded protection } \\
\text { against heterologous TBEV strain } \\
\text { Seroconversion rate comparable to } \\
\text { non-attenuated parental virus }\end{array}$ & [199] \\
\hline 'Naked' non-infectious RNA & $\begin{array}{l}\text { Application of in vitro synthesized } \\
\text { non-infectious, replication-competent } \\
\text { TBEV RNA (carrying an in-frame } \\
\text { deletion of aa28-89 in the C protein with } \\
\text { or without three point mutations } \\
\text { (Gly112Pro; Met113Gln and Leu115Gln)) } \\
\text { - Evaluated in mice }\end{array}$ & Whole TBEV & $+(\mathrm{VN}-\mathrm{Ab})$ & + & + & ++(TBEV) & 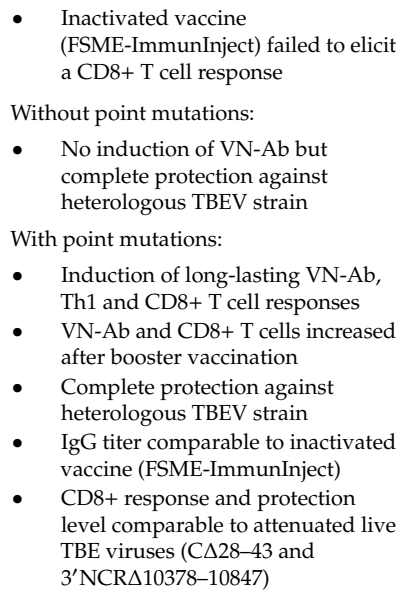 & {$[174,239]$} \\
\hline
\end{tabular}


Table 3. Cont

\begin{tabular}{|c|c|c|c|c|c|c|c|c|}
\hline \multirow{2}{*}{ Approach } & \multirow{2}{*}{ Strategy } & \multirow{2}{*}{$\begin{array}{l}\text { Included TBEV } \\
\text { Target Antigens }\end{array}$} & \multicolumn{3}{|c|}{ TBEV-Specific Adaptive Immunity } & \multirow{2}{*}{$\begin{array}{c}\text { Protection } \\
\text { (Challenge Virus) }\end{array}$} & \multirow{2}{*}{ Comment } & \multirow{2}{*}{ Ref. } \\
\hline & & & Antibodies & CD4+ T Cells & CD8+ T cells & & & \\
\hline \multicolumn{9}{|c|}{ Recombinant adenoviruses (rAds) } \\
\hline Human rAd & $\begin{array}{l}\text { Insertion of TBEV NS1 under control of } \\
\text { CMV major immediate-early promoter } \\
\text { into replication-deficient Rad51 } \Delta \mathrm{E} 1 \\
\text { - Evaluated in mice }\end{array}$ & NS1 & + & n.d. & n.d. & $+(\mathrm{TBEV})$ & & {$[106,107]$} \\
\hline Human rAd & $\begin{array}{l}\text { Insertion of TBEV NS1 into Rad51 } \\
\text { - Evaluated in mice }\end{array}$ & NS1 & + & + & + & $+(\mathrm{TBEV}, \mathrm{OHFV})$ & $\begin{array}{l}\text { - Partial protection against } \\
\text { heterologous TBEV strains } \\
\text { and OHFV } \\
\text { Adoptive transfer of serum, B or T } \\
\text { cells provided partial protection } \\
\text { (for T cells after pre-treatment with } \\
\text { cyclophosphane only) } \\
\text { - CD4+ T cell response: Th1 } \\
\text { - Administration of Rad51-NS1 } \\
\text { together with inactivated TBEV } \\
\text { vaccine potentiated the } \\
\text { immune response }\end{array}$ & [196] \\
\hline \multicolumn{9}{|c|}{ Recombinant Vaccinia viruses (rVACV) } \\
\hline VACV & $\begin{array}{l}\text { Insertion of TBEV NS1 into thymidine } \\
\text { kinase gene under control of early-late } \\
\text { poxvirus P65 promoter into VACV } \\
\text { - Evaluated in mice }\end{array}$ & NS1 & + & n.d. & n.d. & $+(\mathrm{TBEV})$ & $\begin{array}{l}\text { - TBEV challenge dose dictated } \\
\text { protective efficacy }\end{array}$ & [197] \\
\hline VACV & $\begin{array}{l}\text { Insertion of prM-E into a non-replicating } \\
\text { late defective VACV (Uracil DNA } \\
\text { glycosylase deficient) } \\
-\quad \text { Evaluated in mice }\end{array}$ & prM-E & $+(\mathrm{VN}-\mathrm{Ab})$ & n.d. & n.d. & $++/+(\mathrm{TBEV})$ & $\begin{array}{l}\text { Protection against TBEV challenge } \\
\text { infection depended on dose and } \\
\text { route of immunization (s.c. } \\
\text { immunization more efficient than } \\
\text { i.m. and i.p.) }\end{array}$ & [195] \\
\hline VACV & $\begin{array}{l}\text { Insertion of structural and } \\
\text { non-structural BBEV genes into } \\
\text { thymidine kinase gene under control of } \\
\text { VACV 7.5k promoter into VACV } \\
\text { (C-prM-E-NS1 (vC-NS1); } \\
\text { 5'NCR-C-prM-E-NS1-NS2A } \\
\text { (v5'C-NS2A); } \\
\text { C-prM-E-NS1-NS2A-NS2B-NS3 } \\
\text { (vC-NS3)) } \\
\text { - Evaluated in mice }\end{array}$ & $\begin{array}{c}\text { C-prM- } \\
\text { E-NS1/5 } \\
\text { 'NCR-C- } \\
\text { prM-E- } \\
\text { NS1-NS2A/ } \\
\text { C-prM-E- } \\
\text { NS1-NS2A- } \\
\text { NS2B-NS3 }\end{array}$ & $+(\mathrm{VN}-\mathrm{Ab})$ & n.d. & n.d. & $++/+(\mathrm{TBEV})$ & 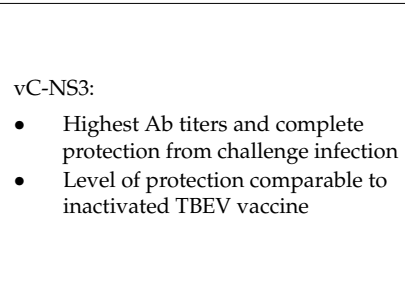 & [211] \\
\hline
\end{tabular}


Table 3. Cont.

\begin{tabular}{|c|c|c|c|c|c|c|c|c|}
\hline \multirow{2}{*}{ Approach } & \multirow{2}{*}{ Strategy } & \multirow{2}{*}{$\begin{array}{l}\text { Included TBEV } \\
\text { Target Antigens }\end{array}$} & \multicolumn{3}{|c|}{ TBEV-Specific Adaptive Immunity } & \multirow{2}{*}{$\begin{array}{c}\text { Protection } \\
\text { (Challenge Virus) }\end{array}$} & \multirow{2}{*}{ Comment } & \multirow{2}{*}{ Ref. } \\
\hline & & & Antibodies & CD4+ T Cells & CD8+ T cells & & & \\
\hline VACV/DNA & $\begin{array}{l}\text { Prime-boost vaccination with VACV and } \\
\text { bacterial plasmid expressing TBEV NS1 } \\
\text { (recombinant VACV: NS1 into } \\
\text { thymidine kinase gene under control of } \\
\text { synthetic early-late poxvirus promoter; } \\
\text { bacterial plasmid: NS1 under control of } \\
\text { CMV immediate-early promoter) } \\
\text { - Evaluated in mice }\end{array}$ & NS1 & + & n.d. & n.d. & +(TBEV) & $\begin{array}{ll}\text { - } & \text { Partial protection against } \\
\text { heterologous TBEV strain } \\
\text { - Higher protective efficacy upon } \\
\text { VACV prime/plasmid boost } \\
\text { compared to plasmid } \\
\text { prime/VACV boost }\end{array}$ & [246] \\
\hline \multicolumn{9}{|c|}{ Live attenuated viruses } \\
\hline LGTV & $\begin{array}{l}\text { Administration of attenuated LGTV } \\
\text { strain } \\
\text { - Evaluated in humans }\end{array}$ & Whole LGTV & + & n.d. & n.d. & +(field study) & $\begin{array}{ll}\text { - } & \text { Tested in } 649,470 \text { volunteers } \\
\text { Single immunization induced } \\
\text { long-lasting seroconversion in } \\
100 \% \text { of individuals } \\
\text { - } \\
\text { Reduced incidence of TBEV in } \\
\text { endemic regions } \\
\text { - } & \text { High incidence of severe } \\
\text { neurological reverse advents } \\
\text { No absolute protection against } \\
\text { TBEV in endemic regions }\end{array}$ & [200] \\
\hline Attenuated TBEV & $\begin{array}{l}\text { Attenuation of TBEV by introducing } \\
\text { deletions in the variable } 3^{\prime} \mathrm{NCR} \text { region } \\
\text { - Evaluated in mice }\end{array}$ & Whole TBEV & + & n.d. & n.d. & $++(\mathrm{TBEV})$ & $\begin{array}{ll}\text { - Genetically stable, } \\
\text { attenuated phenotype } \\
\text { Immunization afforded protection } \\
\text { against heterologous TBEV strain } \\
\text { - i.c. inoculation of suckling mice } \\
\text { showed remaining neurovirulence } \\
\text { (slight reduction of neurovirulence; } \\
\text { manifested in longer mean } \\
\text { survival time) }\end{array}$ & [218] \\
\hline Attenuated TBEV & $\begin{array}{l}\text { Introduction of single or multiple } \\
\text { mutations in EDIII (aa308-311), } \\
\text { combination of mutations in the } 3^{\prime} \mathrm{NCR} \\
\text { with mutations at EDIII aa310 } \\
\text { - Evaluated in mice }\end{array}$ & Whole TBEV & + & n.d. & n.d. & $++(\mathrm{TBEV})$ & 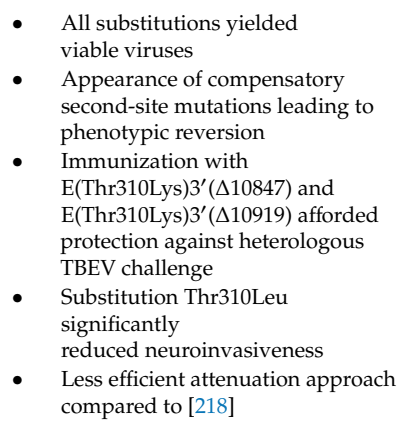 & [217] \\
\hline
\end{tabular}


Table 3. Cont

\begin{tabular}{|c|c|c|c|c|c|c|c|c|}
\hline \multirow{2}{*}{ Approach } & \multirow{2}{*}{ Strategy } & \multirow{2}{*}{$\begin{array}{l}\text { Included TBEV } \\
\text { Target Antigens }\end{array}$} & \multicolumn{3}{|c|}{ TBEV-Specific Adaptive Immunity } & \multirow{2}{*}{$\begin{array}{c}\text { Protection } \\
\text { (Challenge Virus) }\end{array}$} & \multirow{2}{*}{ Comment } & \multirow{2}{*}{ Ref. } \\
\hline & & & Antibodies & CD4+ T Cells & CD8+ T cells & & & \\
\hline Attenuated TBEV & $\begin{array}{l}\text { Multiple passaging of TBEV in BHK-21 } \\
\text { cells and selection of binding mutants } \\
\text { with high heparin sulfate affinity } \\
\text { - Evaluated in mice }\end{array}$ & Whole TBEV & + & n.d. & n.d. & $++(\mathrm{TBEV})$ & $\begin{array}{l}\text { E protein mutants Glu201Lys, } \\
\text { Glu122Gly, Ser158Arg/Gly159Arg } \\
\text { showed reduced } \\
\text { neuroinvasiveness and afforded } \\
\text { protection against heterologous } \\
\text { TBEV challenge }\end{array}$ & [219] \\
\hline Attenuated TBEV & $\begin{array}{l}\text { Introduction of deletions into the TBEV } \\
\mathrm{C} \text { protein (4-21 aa deletions starting at } \\
\text { aa28 of C) } \\
-\quad \text { Evaluated in mice }\end{array}$ & Whole TBEV & + & n.d. & n.d. & $++(\mathrm{TBEV})$ & $\begin{array}{ll}\text { - } & \text { Highly attenuated phenotype } \\
\text { Introduction of deletions led to } \\
\text { VLP production } \\
\text { Mutant } C(\Delta 28-43) \text { showed reduced } \\
\text { neuroinvasiveness and afforded } \\
\text { protection against heterologous } \\
\text { TBEV challenge }\end{array}$ & [216] \\
\hline Attenuated TBEV & $\begin{array}{l}\text { Introduction of deletions into the TBEV } \\
\text { C protein }(19,21,27 \text { or } 30 \text { aa deletions } \\
\text { starting at aa } 28 \text { of } C) \\
\text { - Evaluated in mice }\end{array}$ & Whole TBEV & + & n.d. & n.d. & $++(\mathrm{TBEV})$ & $\begin{array}{l}\text { - Appearance of compensatory } \\
\text { second-site mutations in the C } \\
\text { protein upon passaging } \\
\text { - Second-site mutation Gln70Leu or } \\
\text { duplication Ile78-Leu85 restored } \\
\text { viability of the parental virus } \\
\text { C }(\Delta 28-48) \\
\text { - }(\Delta 28-48 / \text { Gln70Leu }) \text { and } \\
\text { C }(\Delta 28-48 / \text { Du78-85): } \\
\text { - Highly attenuated phenotype } \\
\text { Protection against heterologous } \\
\text { TBEV challenge } \\
\text { - Seroconversion rate superior } \\
\text { compared to } C(\Delta 28-43)\end{array}$ & [220] \\
\hline Attenuated TBEV & $\begin{array}{l}\text { Large-scale random codon re-encoding, } \\
\text { random introduction of } 273 \\
\text { synonymous mutations into NS5 } \\
\text { - Evaluated in mice }\end{array}$ & Whole TBEV & $+(\mathrm{VN}-\mathrm{Ab})$ & n.d. & n.d. & $++(\mathrm{TBEV})$ & $\begin{array}{l}\text { - Compared to wild type virus: } \\
\text { attenuated phenotype, reduced } \\
\text { neurovirulence, reduced } \\
\text { neuroinvasiveness, comparable } \\
\text { VN-Ab levels }\end{array}$ & [214] \\
\hline
\end{tabular}


Table 3. Cont.

\begin{tabular}{|c|c|c|c|c|c|c|c|c|}
\hline \multirow{2}{*}{ Approach } & \multirow{2}{*}{ Strategy } & \multirow{2}{*}{$\begin{array}{l}\text { Included TBEV } \\
\text { Target Antigens }\end{array}$} & \multicolumn{3}{|c|}{ TBEV-Specific Adaptive Immunity } & \multirow{2}{*}{$\begin{array}{c}\text { Protection } \\
\text { (Challenge Virus) }\end{array}$} & \multirow{2}{*}{ Comment } & \multirow{2}{*}{ Ref. } \\
\hline & & & Antibodies & CD4+ T Cells & CD8+ T cells & & & \\
\hline \multicolumn{9}{|c|}{ Flavivirus chimera } \\
\hline JEV-based & $\begin{array}{l}\text { Replacement of prM-E from JEV live } \\
\text { vaccine strain SA14-14-2 by } \\
\text { corresponding genes from TBEV } \\
\text { (ChinTBEV) } \\
\text { - Evaluated in mice }\end{array}$ & prM-E & $+(\mathrm{VN}-\mathrm{Ab})$ & n.d. & n.d. & ++/+(TBEV) & $\begin{array}{ll}\text { - } & \text { Attenuated phenotype but } \\
& \text { remaining neurovirulence } \\
\text { - } & \text { Protection against TBEV challenge } \\
\text { infection depended on dose and } \\
\text { route of immunization (i.p. or s.c.) }\end{array}$ & [224] \\
\hline $\begin{array}{l}\text { YFV 17D-, DENV-2- or } \\
\text { LGTV-based }\end{array}$ & $\begin{array}{l}\text { Replacement of prM-E from YFV 17D, } \\
\text { DENV-2 or LGTV by corresponding } \\
\text { genes from TBEV } \\
\text { - Evaluated in mice }\end{array}$ & prM-E & $+(\mathrm{VN}-\mathrm{Ab})$ & + & n.d. & ++/+(TBEV) & $\begin{array}{ll}\text { - } & \text { Reduced neuroinvasiveness but } \\
\text { high neurovirulence } \\
\text { (under-attenuation) } \\
\text { VN-Ab titer higher in YFV/TBEV } \\
\text { than DENV-2/TBEV } \\
\text { vaccinated mice } \\
\text { - Protection levels differed among } \\
\text { immunization with chimera } \\
\text { (YFV/TBEV: 100\% survival, } \\
\text { DENV-2/TBEV: } 85.7 \% \text { survival) } \\
\text { CD4+ T cell response: Th1 } \\
\text { (YFV/TBEV) }\end{array}$ & [223] \\
\hline RepliVax (RV) platform & $\begin{array}{l}\text { Replacement of prM-E from different } \\
\text { flaviviruses (WNV, LGTV, TBEV or YFV } \\
\text { 17D) by corresponding genes from TBEV, } \\
\text { attenuation due to deletion in C } \\
\text { - Evaluated in mice and NHP }\end{array}$ & prM-E & $\begin{array}{l}+(\mathrm{VN}-\mathrm{Ab} \text { in } \\
\text { mice + NHP) }\end{array}$ & + & n.d. & $\begin{array}{l}\text { ++/+(TBEV: mice, } \\
\text { LGTV: NHP) }\end{array}$ & $\begin{array}{l}\text { - } \quad \text { Highly attenuated in mice } \\
\text { RV-WNV/TBEV: } \\
\text { - Suitable for heterologous } \\
\text { prime-boost vaccination with } \\
\text { inactivated vaccine } \\
\text { (FSME-IMMUN) } \\
\text { - Only moderate effect of WNV } \\
\text { pre-existing immunity } \\
\text { Mice: } \\
\text { - Protection levels differed among } \\
\text { immunization with chimera } \\
\text { (RV-WNV/TBEV and } \\
\text { RV-TBEV/TBEV: 100\% survival, } \\
\text { RV-YFV/TBEV: 50\% survival) } \\
\text { VN-Ab titer highest for } \\
\text { R-WNV/TBEV and lowest for } \\
\text { RV-YFV/TBEV } \\
\text { CD4+ T cell response: Th1 } \\
\text { (RV-WNV/TBEV) } \\
\text { NHP: } \\
\text { - Protection depended on dose and } \\
\text { application method (i.d., i.m. } \\
\text { or s.c.) } \\
\text { RV-WNV/TBEV higher } \\
\text { immunogenicity and more durable } \\
\text { immunity compared to inactivated } \\
\text { vaccine (FSME-IMMUN) }\end{array}$ & [223] \\
\hline
\end{tabular}


Table 3. Cont.

\begin{tabular}{|c|c|c|c|c|c|c|c|c|}
\hline \multirow{2}{*}{ Approach } & \multirow{2}{*}{ Strategy } & \multirow{2}{*}{$\begin{array}{l}\text { Included TBEV } \\
\text { Target Antigens }\end{array}$} & \multicolumn{3}{|c|}{ TBEV-Specific Adaptive Immunity } & \multirow{2}{*}{$\begin{array}{c}\text { Protection } \\
\text { (Challenge Virus) }\end{array}$} & \multirow{2}{*}{ Comment } & \multirow{2}{*}{ Ref. } \\
\hline & & & Antibodies & CD4+ T Cells & CD8+ T cells & & & \\
\hline LGTV-based & $\begin{array}{l}\text { Replacement of prM-E of DENV-4 with } \\
\text { corresponding genes from LGTV } \\
\text { (LGTV/DENV-4) } \\
\text { - Evaluated in humans (phase I trial) }\end{array}$ & prM-E & $\begin{array}{c}+(\mathrm{VN}-\mathrm{Ab} \\
\text { against LGTV }+ \\
\text { TBEV) }\end{array}$ & n.d. & n.d. & n.d. & $\begin{array}{ll}\text { - } & \text { Good safety profile } \\
\text { High seroconversion rates against } \\
\text { LGTV }(80 \%) \text { but low against TBEV } \\
(35 \%) \\
\text { - Low cross-reactive Ab response } \\
\text { against TBEV, no increase observed } \\
\text { post booster vaccination }\end{array}$ & [237] \\
\hline DENV-4-based & $\begin{array}{l}\text { Replacement of prM-E of DENV-4 with } \\
\text { corresponding genes from TBEV } \\
\text { (TBEV/DENV-4) } \\
\text { - Evaluated in mice and NHP }\end{array}$ & prM-E & $\begin{array}{l}+(\mathrm{VN}-\mathrm{Ab} \text { in } \\
\text { NHP; n.d. for } \\
\text { mice) }\end{array}$ & n.d. & n.d. & + (LGTV) & $\begin{array}{l}\text { Mice: } \\
\text { - } \quad \begin{array}{l}\text { High neurovirulence (suckling } \\
\text { mice), reduced neuroinvasiveness } \\
\text { (SCID mice) }\end{array} \\
\text { NHP: } \\
\text { - } \quad \text { High VN-Ab titer against TBEV } \\
\text { and LGTV (ratio 5:1) } \\
\text { VN-Ab titers higher than induced } \\
\text { by TBEV/DENV-4A30 (see below) } \\
\text { Booster vaccination } \\
\text { enhanced VN-Ab } \\
\text { VN-Ab titer against TBEV lower } \\
\text { compared to immunization with } \\
\text { inactivated TBEV vaccine } \\
\text { (Encepur) } \\
\text { Protection against viremia upon } \\
\text { LGTV challenge infection } \\
\text { - No attenuated phenotype }\end{array}$ & [233] \\
\hline DENV-4-based & $\begin{array}{l}\text { Replacement of prM-E of DENV-4 with } \\
\text { corresponding genes from TBEV and } \\
\text { introduction of a } 30 \text { nt deletion in the } \\
\text { DENV-4 } 3^{\prime} \text { NCR (TBEV/DENV-4 } 430 \text { ) } \\
\text { - Evaluated in mice and NHP }\end{array}$ & prM-E & $\begin{array}{l}+(\mathrm{VN}-\mathrm{Ab} \text { in } \\
\text { NHP; n.d. for } \\
\text { mice) }\end{array}$ & n.d. & n.d. & + (LGTV) & $\begin{array}{l}\text { Mice: } \\
\text { - } \quad \begin{array}{l}\text { High neurovirulence (suckling } \\
\text { mice), reduced neuroinvasiveness } \\
\text { (SCID mice) }\end{array} \\
\text { NHP: } \\
\text { - } \quad \text { VN-Ab against TBEV and LGTV } \\
\text { (ratio 3.5:1) } \\
\text { - VN-Ab titers lower compared to } \\
\text { LGTV/DENV-4 } \\
\text { - Booster vaccination } \\
\text { enhanced VN-Ab } \\
\text { - VN-Ab titer against TBEV lower } \\
\text { than induced by inactivated TBEV } \\
\text { vaccine (Encepur) } \\
\text { - Significantly attenuated phenotype } \\
\text { but still neurovirulent } \\
\text { (histopathological lesions) } \\
\text { - Protection against viremia upon } \\
\text { LGTV challenge infection }\end{array}$ & {$[233,234]$} \\
\hline
\end{tabular}


Table 3. Cont.

\begin{tabular}{|c|c|c|c|c|c|c|c|c|}
\hline \multirow{2}{*}{ Approach } & \multirow{2}{*}{ Strategy } & \multirow{2}{*}{$\begin{array}{l}\text { Included TBEV } \\
\text { Target Antigens }\end{array}$} & \multicolumn{3}{|c|}{ TBEV-Specific Adaptive Immunity } & \multirow{2}{*}{$\begin{array}{c}\text { Protection } \\
\text { (Challenge Virus) }\end{array}$} & \multirow{2}{*}{ Comment } & \multirow{2}{*}{ Ref. } \\
\hline & & & Antibodies & CD4+ T Cells & CD8+ T cells & & & \\
\hline DENV-4-based & $\begin{array}{l}\text { Introduction of single or multiple } \\
\text { mutations into TBEV/DENV-4A30 } \\
\text { (deletion of } 30 \mathrm{nt} \text { in } 3^{\prime} \text { NCR of DENV-4; } \\
\text { mutations in TBEV E (aa315) and } \\
\text { DENV-4 NS5 (aa654, aa655)) } \\
\text { - Evaluated in mice }\end{array}$ & prM-E & n.d. & n.d. & n.d. & n.d. & $\begin{array}{l}\text { TBEV/DENV-4 } 430 \text { was further } \\
\text { attenuated in its neurovirulence, } \\
\text { neuroinvasiveness } \\
\text { and neuro-pathology } \\
\text { Mutations are genetically stable } \\
\text { in mice } \\
\text { Mutant with multiple mutations } \\
\text { (v } \Delta 30 / E 315 / N S 5654,655 \text { ) showed } \\
\text { highest attenuation level of } \\
\text { neuroinvasiveness } \\
\text { and neurovirulence }\end{array}$ & [232] \\
\hline $\begin{array}{l}\text { miRNA targeted flavivirus } \\
\text { chimera }\end{array}$ & $\begin{array}{l}\text { Replacement of DENV-4 prM-E by } \\
\text { corresponding genes from TBEV and } \\
\text { introduction of single or multiple } \\
\text { miRNA targeting sequences for cellular } \\
\text { CNS-specific miRNAs into the 3'NCR of } \\
\text { TBEV/DENV-4 } \\
\text { - Evaluated in mice and NHP }\end{array}$ & prM-E & $\begin{array}{l}+(\mathrm{VN}-\mathrm{Ab} \text { in } \\
\text { mice + NHP) }\end{array}$ & n.d. & n.d. & $\begin{array}{c}\text { ++/+(Parental } \\
\text { TBEV/DENV-4: } \\
\text { mice) }\end{array}$ & 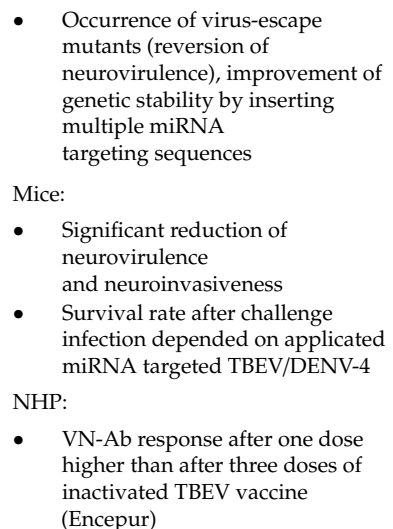 & $\begin{array}{l}{[228]} \\
{[229]}\end{array}$ \\
\hline
\end{tabular}


Table 3. Cont.

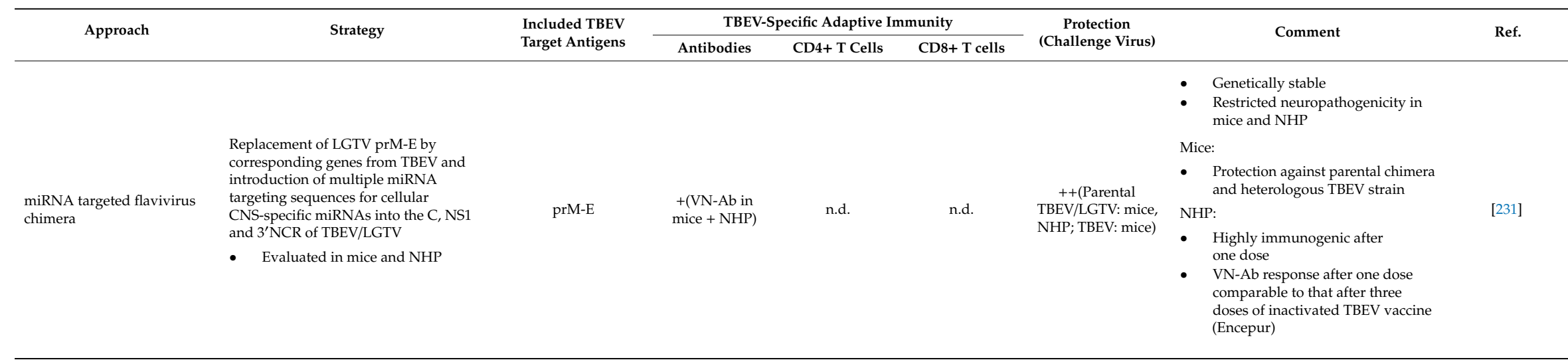

Legend: ++: complete protection, +: partial protection/presence of antibodies/CD4 ${ }^{+} \mathrm{T}$ cells/CD8 ${ }^{+} \mathrm{T}$ cells, $-:$ no protection/absence of antibodies/CD4 ${ }^{+} \mathrm{T}$ cells/CD8 ${ }^{+} \mathrm{T}$ cells, .d.: not determined. Abbreviations: $\Delta$ : deletion, aa: amino acid(s), Ab: antibodies, Ad: adenovirus, Arg: arginine, BHK-21 cells: baby hamster kidney cells, C: capsid protein, CMV: cytomegalovirus, CNS: central nervous system, COS-1 cells: green monkey kidney cells, DENV-2/-4: dengue virus serotype 2/4, Du: duplication, E: envelope protein, Gln: glutamine, Glu: glutamic acid, Gly: glycine, i.c.: intracranial, i.d.: intradermal, IgG: immunoglobulin G, Ile: isoleucine, i.m.: intramuscular, i.p.: intraperitoneal, JEV: Japanese encephalitis virus, Leu: leucine, LGTV: Langat virus, Lys: lysine, Met: methionine, miRNA: microRNA, NCR: non-coding region, NHP: non-human primates, NS: non-structural protein, nt: nucleotides, OHFV: Omsk hemorrhagic fever virus, prM: precursor-membrane protein, Pro: proline, rAd/Rad: recombinant adenovirus, Ref.: reference, RV: RepliVax, s.c.: subcutaneous., SCID: severe combined immunodeficient, Ser: serine, TBEV: tick-borne encephalitis virus, Th: T helper cell, Thr: threonine, VACV: Vaccinia virus, VLP: virus-like particle, VN: virus-neutralizing, WNV: West Nile virus, YFV: Yellow fever virus. 
Author Contributions: Conceptualization, writing-review and editing, G.F.R.; writing-original draft preparation, J.B. and M.K.; review and editing, T.G., A.V. and G.S. All authors have read and agreed to the published version of the manuscript.

Funding: This research was funded by the Deutsche Forschungsgemeinschaft (DFG, German Research Foundation) - 398066876/GRK 2485/1 and by the Alexander von Humboldt Foundation in the framework of the Alexander von Humboldt Professorship endowed by the German Federal Ministry of Education and Research. This publication was supported by DFG and University of Veterinary Medicine Hannover, Foundation within the funding program Open Access Publishing.

Conflicts of Interest: The authors declare no conflict of interest.

\section{References}

1. Simmonds, P.; Becher, P.; Bukh, J.; Gould, E.A.; Meyers, G.; Monath, T.; Muerhoff, S.; Pletnev, A.; Rico-Hesse, R.; Smith, D.B.; et al. ICTV Virus Taxonomy Profile: Flaviviridae. J. Gen. Virol. 2017, 98, 2-3. [CrossRef] [PubMed]

2. World Health Organisation. Vaccines against tick-borne encephalitis: WHO Position Paper. Wkly. Epidemiol. Rec. = Relev. Épidémiologique Hebd. 2011, 86, 241-256.

3. Ruzek, D.; Avšič Županc, T.; Borde, J.; Chrdle, A.; Eyer, L.; Karganova, G.; Kholodilov, I.; Knap, N.; Kozlovskaya, L.; Matveev, A.; et al. Tick-borne encephalitis in Europe and Russia: Review of pathogenesis, clinical features, therapy, and vaccines. Antivir. Res. 2019, 164, 23-51. [CrossRef]

4. Pulkkinen, L.I.A.; Butcher, S.J.; Anastasina, M. Tick-Borne Encephalitis Virus: A Structural View. Viruses 2018, 10, 350. [CrossRef] [PubMed]

5. Füzik, T.; Formanová, P.; Růžek, D.; Yoshii, K.; Niedrig, M.; Plevka, P. Structure of tick-borne encephalitis virus and its neutralization by a monoclonal antibody. Nat. Commun. 2018, 9, 1-11. [CrossRef]

6. Růžek, D.; Yoshii, K.; Bloom, M.E.; Gould, E.A. Virology. In The TBE Book; Dobler, G., Erber, W., Bröker, M., Schmitt, H.-J., Eds.; Global Health Press: Singapore, 2020; pp. 16-31.

7. Heinz, F.X.; Stiasny, K.; Püschner-Auer, G.; Holzmann, H.; Allison, S.L.; Mandl, C.W.; Kunz, C. Structural Changes and Functional Control of the Tick-Borne Encephalitis Virus Glycoprotein E by the Heterodimeric Association with Protein prM. Virology 1994, 198, 109-117. [CrossRef]

8. Elshuber, S.; Allison, S.L.; Heinz, F.X.; Mandl, C.W. Cleavage of protein prM is necessary for infection of BHK-21 cells by tick-borne encephalitis virus. J. Gen. Virol. 2003, 84, 183-191. [CrossRef]

9. Stadler, K.; Allison, S.L.; Schalich, J.; Heinz, F.X. Proteolytic Activation of Tick-Borne Encephalitis Virus by Furin. J. Virol. 1997, 71, 8475-8481. [CrossRef]

10. Heinz, F.X.; Allison, S.L. Flavivirus Structure and Membrane Fusion. Adv. Virus Res. 2003, 59, 63-97. [CrossRef]

11. Crooks, A.J.; Lee, J.M.; Easterbrook, L.M.; Timofeev, A.V.; Stephenson, J.R. The NS1 protein of tick-borne encephalitis virus forms multimeric species upon secretion from the host cell. J. Gen. Virol. 1994, 75, 3453-3460. [CrossRef]

12. Bogovic, P.; Strle, F. Tick-borne encephalitis: A review of epidemiology, clinical characteristics, and management. World J. Clin. Cases 2015, 3, 430-441. [CrossRef]

13. Balogh, Z.; Ferenczi, E.; Szeles, K.; Stefanoff, P.; Gut, W.; Szomor, K.N.; Takacs, M.; Berencsi, G. Tick-borne encephalitis outbreak in Hungary due to consumption of raw goat milk. J. Virol. Methods 2010, 163, 481-485. [CrossRef]

14. Caini, S.; Szomor, K.; Ferenczi, E.; Székelyné Gáspár, Á.; Csohán, Á.; Krisztalovics, K.; Molnár, Z.; Horváth, J.K. Tick-borne encephalitis transmitted by unpasteurised cow milk in western Hungary, September to October 2011. Eurosurveillance 2012, 17, 20128. [PubMed]

15. Dorko, E.; Hockicko, J.; Rimárová, K.; Bušová, A.; Popad'ák, P.; Popad'áková, J.; Schréter, I. Milk outbreaks of tick-borne encephalitis in Slovakia, 2012-2016. Cent. Eur. J. Public Health 2018, 26, S47-S50. [CrossRef] [PubMed]

16. Holzmann, H.; Aberle, S.W.; Stiasny, K.; Werner, P.; Mischak, A.; Zainer, B.; Netzer, M.; Koppi, S.; Bechter, E.; Heinz, F.X. Tick-borne Encephalitis from Eating Goat Cheese in a Mountain Region of Austria. Emerg. Infect. Dis. 2009, 15, 1671-1673. [CrossRef] 
17. Hudopisk, N.; Korva, M.; Janet, E.; Simetinger, M.; Grgič-Vitek, M.; Gubenšek, J.; Natek, V.; Kraigher, A.; Strle, F.; Avšič-Županc, T. Tick-borne Encephalitis Associated with Consumption of Raw Goat Milk, Slovenia, 2012. Emerg. Infect. Dis. 2013, 19, 806-808. [CrossRef]

18. Lindquist, L.; Vapalahti, O. Tick-borne encephalitis. Lancet 2008, 371, 1861-1871. [CrossRef]

19. Dai, X.; Shang, G.; Lu, S.; Yang, J.; Xu, J. A new subtype of eastern tick-borne encephalitis virus discovered in Qinghai-Tibet Plateau, China. Emerg. Microbes Infect. 2018, 7, 74. [CrossRef] [PubMed]

20. Kovalev, S.Y.; Mukhacheva, T.A. Reconsidering the classification of tick-borne encephalitis virus within the Siberian subtype gives new insights into its evolutionary history. Infect. Genet. Evol. 2017, 55, 159-165. [CrossRef] [PubMed]

21. Erber, W.; Schmitt, H.-J.; Janković, T.V. TBE-epidemiology by country-An overview. In The TBE Book; Dobler, G., Erber, W., Bröker, M., Schmitt, H.-J., Eds.; Global Health Press: Singapore, 2020; pp. 159-170.

22. Boelke, M.; Bestehorn, M.; Marchwald, B.; Kubinski, M.; Liebig, K.; Glanz, J.; Schulz, C.; Dobler, G.; Monazahian, M.; Becker, S.C. First Isolation and Phylogenetic Analyses of Tick-Borne Encephalitis Virus in Lower Saxony, Germany. Viruses 2019, 11, 462. [CrossRef] [PubMed]

23. De Graaf, J.A.; Reimerink, J.H.J.; Voorn, G.P.; De Vaate, E.A.L.B.; De Vries, A.; Rockx, B.; Schuitemaker, A.; Hira, V. First human case of tick-borne encephalitis virus infection acquired in the Netherlands, July 2016. Eurosurveillance 2016, 21, 30318. [CrossRef] [PubMed]

24. Holding, M.; Dowall, S.D.; Medlock, J.M.; Carter, D.P.; McGinley, L.; Curran-French, M.; Pullan, S.T.; Chamberlain, J.; Hansford, K.M.; Baylis, M.; et al. Detection of new endemic focus of tick-borne encephalitis virus (TBEV), Hampshire/Dorset border, England, September 2019. Eurosurveillance 2019, 24, 1900658. [CrossRef] [PubMed]

25. Holding, M.; Dowall, S.D.; Medlock, J.M.; Carter, D.P.; Pullan, S.T.; Lewis, J.; Vipond, R.; Rocchi, M.S.; Baylis, M.; Hewson, R. Tick-Borne Encephalitis Virus, United Kingdom. Emerg. Infect. Dis. 2020, 26, 90-96. [CrossRef] [PubMed]

26. Wallenhammar, A.; Lindqvist, R.; Asghar, N.; Gunaltay, S.; Fredlund, H.; Davidsson, Å.; Andersson, S.; Överby, A.K.; Johansson, M. Revealing new tick-borne encephalitis virus foci by screening antibodies in sheep milk. Parasit. Vectors 2020, 13, 185. [CrossRef] [PubMed]

27. Randolph, S.E. To what extent has climate change contributed to the recent epidemiology of tick-borne diseases? Vet. Parasitol. 2010, 167, 92-94. [CrossRef] [PubMed]

28. Randolph, S.E.; Asokliene, L.; Avsic-Zupanc, T.; Bormane, A.; Burri, C.; Gern, L.; Golovljova, I.; Hubalek, Z.; Knap, N.; Kondrusik, M.; et al. Variable spikes in tick-borne encephalitis incidence in 2006 independent of variable tick abundance but related to weather. Parasit. Vectors 2008, 1, 44. [CrossRef]

29. Agergaard, C.N.; Rosenstierne, M.W.; Bødker, R.; Rasmussen, M.; Andersen, P.H.S.; Fomsgaard, A. New tick-borne encephalitis virus hot spot in Northern Zealand, Denmark, October 2019. Eurosurveillance 2019, 24, 1900639. [CrossRef]

30. Mikryukova, T.P.; Moskvitina, N.S.; Kononova, Y.V.; Korobitsyn, I.G.; Kartashov, M.Y.; Tyuten'kov, O.Y.; Protopopova, E.V.; Romanenko, V.N.; Chausov, E.V.; Gashkov, S.I.; et al. Surveillance of tick-borne encephalitis virus in wild birds and ticks in Tomsk city and its suburbs (Western Siberia). Ticks Tick-Borne Dis. 2014, 5, 145-151. [CrossRef]

31. Růžek, D.; Dobler, G.; Mantke, O.D. Tick-borne encephalitis: Pathogenesis and clinical implications. Travel Med. Infect. Dis. 2010, 8, 223-232. [CrossRef]

32. Centers for Disease Control and Prevention. Tick-Borne Encephalitis among U.S. Travelers to Europe and Asia-2000-2009. Morb. Mortal. Wkly. Rep. 2010, 59, 335-338.

33. Dobler, G.; Gniel, D.; Petermann, R.; Pfeffer, M. Epidemiology and distribution of tick-borne encephalitis. Wien. Med. Wochenschr. 2012, 162, 230-238. [CrossRef] [PubMed]

34. Kollaritsch, H.; Paulke-Korinek, M.; Holzmann, H.; Hombach, J.; Bjorvatn, B.; Barrett, A. Vaccines and vaccination against tick-borne encephalitis. Expert Rev. Vaccines 2012, 11, 1103-1119. [CrossRef] [PubMed]

35. Dobler, G. Zoonotic tick-borne flaviviruses. Vet. Microbiol. 2010, 140, 221-228. [CrossRef]

36. Holzmann, H. Diagnosis of tick-borne encephalitis. Vaccine 2003, 21, S1/36-S1/40. [CrossRef]

37. Xing, Y.; Schmitt, H.-J.; Arguedas, A.; Junfeng, Y. Tick-borne encephalitis in China: A review of epidemiology and vaccines. Vaccine 2017, 35, 1227-1237. [CrossRef]

38. Lu, Z.; Broeker, M.; Liang, G. Tick-Borne Encephalitis in Mainland China. Vector-Borne Zoonotic Dis. 2008, 8, 713-720. [CrossRef] [PubMed] 
39. Barrett, P.N.; Schober-Bendixen, S.; Ehrlich, H.J. History of TBE vaccines. Vaccine 2003, 21, S1/41-S1/49. [CrossRef]

40. Klockmann, U.; Bock, H.L.; Franke, V.; Hein, B.; Reiner, G.; Hilfenhaus, J. Preclinical investigations of the safety, immunogenicity and efficacy of a purified, inactivated tick-borne encephalitis vaccine. J. Biol. Stand. 1989, 17, 331-342. [CrossRef]

41. Vorovitch, M.F.; Grishina, K.G.; Volok, V.P.; Chernokhaeva, L.L.; Grishin, K.V.; Karganova, G.G.; Ishmukhametov, A.A. Evervac: Phase I/II study of immunogenicity and safety of a new adjuvant-free TBE vaccine cultivated in Vero cell culture. Hum. Vaccin. Immunother. 2020. [CrossRef]

42. Pöllabauer, E.M.; Kollaritsch, H. Prevention: Vaccines and immunoglobulins. In The TBE Book; Dobler, G., Erber, W., Bröker, M., Schmitt, H.-J., Eds.; Global Health Press: Singapore, 2020; pp. 363-380.

43. Wittermann, C.; Schöndorf, I.; Gniel, D. Antibody response following administration of two paediatric tick-borne encephalitis vaccines using two different vaccination schedules. Vaccine 2009, 27, 1661-1666. [CrossRef]

44. Prymula, R.; Pöllabauer, E.M.; Pavlova, B.G.; Löw-Baselli, A.; Fritsch, S.; Angermayr, R.; Geisberger, A.; Barrett, P.N.; Ehrlich, H.J. Antibody persistence after two vaccinations with either FSME-IMMUN@Junior or ENCEPUR®Children followed by third vaccination with FSME-IMMUN®Junior. Hum. Vaccin. Immunother. 2012, 8, 736-742. [CrossRef] [PubMed]

45. Demicheli, V.; Debalini, M.G.; Rivetti, A. Vaccines for preventing tick-borne encephalitis (Review). Cochrane Database Syst. Rev. 2009. [CrossRef]

46. Beran, J.; Xie, F.; Zent, O. Five year follow-up after a first booster vaccination against tick-borne encephalitis following different primary vaccination schedules demonstrates long-term antibody persistence and safety. Vaccine 2014, 32, 4275-4280. [CrossRef] [PubMed]

47. Schöndorf, I.; Beran, J.; Cizkova, D.; Lesna, V.; Banzhoff, A.; Zent, O. Tick-borne encephalitis (TBE) vaccination: Applying the most suitable vaccination schedule. Vaccine 2007, 25, 1470-1475. [CrossRef] [PubMed]

48. Zent, O.; Beran, J.; Jilg, W.; Mach, T.; Banzhoff, A. Clinical evaluation of a polygeline-free tick-borne encephalitis vaccine for adolescents and adults. Vaccine 2003, 21, 738-741. [CrossRef]

49. Loew-Baselli, A.; Poellabauer, E.-M.; Pavlova, B.G.; Koska, M.; Bobrovsky, R.; Konior, R.; Ehrlich, H.J. Seropersistence of tick-borne encephalitis antibodies, safety and booster response to FSME-IMMUN@0.5 ml in adults aged 18-67 years. Hum. Vaccin. 2009, 5, 551-556. [CrossRef]

50. Pavlova, B.G.; Loew-Baselli, A.; Fritsch, S.; Poellabauer, E.-M.; Vartian, N.; Rinke, I.; Ehrlich, H.J. Tolerability of modified tick-borne encephalitis vaccine FSME-IMMUN “NEW" in children: Results of post-marketing surveillance. Vaccine 2003, 21, 742-745. [CrossRef]

51. Vorovitch, M.F.; Maikova, G.B.; Chernokhaeva, L.L.; Romanenko, V.V.; Karganova, G.G.; Ishmukhametov, A.A. Comparison of the Immunogenicity and Safety of Two Pediatric TBE Vaccines Based on the Far Eastern and European Virus Subtypes. Adv. Virol. 2019, 2019. [CrossRef]

52. Maikova, G.B.; Chernokhaeva, L.L.; Rogova, Y.V.; Kozlovskaya, L.I.; Kholodilov, I.S.; Romanenko, V.V.; Esyunina, M.S.; Ankudinova, A.A.; Kilyachina, A.S.; Vorovitch, M.F.; et al. Ability of inactivated vaccines based on far-eastern tick-borne encephalitis virus strains to induce humoral immune response in originally seropositive and seronegative recipients. J. Med. Virol. 2019, 91, 190-200. [CrossRef]

53. Yoshii, K.; Song, J.Y.; Park, S.-B.; Yang, J.; Schmitt, H.-J. Tick-borne encephalitis in Japan, Republic of Korea and China. Emerg. Microbes Infect. 2017, 6, 1-10. [CrossRef]

54. Wittermann, C.; Petri, E.; Zent, O. Long-term persistence of tick-borne encephalitis antibodies in children 5 years after first booster vaccination with Encepur@Children. Vaccine 2009, 27, 1585-1588. [CrossRef] [PubMed]

55. Rendi-Wagner, P.; Kundi, M.; Zent, O.; Dvorak, G.; Jaehnig, P.; Holzmann, H.; Mikolasek, A.; Kollaritsch, H. Persistence of protective immunity following vaccination against tick-borne encephalitis-Longer than expected? Vaccine 2004, 22, 2743-2749. [CrossRef] [PubMed]

56. Hainz, U.; Jenewein, B.; Asch, E.; Pfeiffer, K.-P.; Berger, P.; Grubeck-Loebenstein, B. Insufficient protection for healthy elderly adults by tetanus and TBE vaccines. Vaccine 2005, 23, 3232-3235. [CrossRef]

57. Weinberger, B.; Keller, M.; Fischer, K.-H.; Stiasny, K.; Neuner, C.; Heinz, F.X.; Grubeck-Loebenstein, B. Decreased antibody titers and booster responses in tick-borne encephalitis vaccinees aged 50-90 years. Vaccine 2010, 28, 3511-3515. [CrossRef] 
58. Zavadska, D.; Anca, I.; André, F.; Bakir, M.; Chlibek, R.; Čižman, M.; Ivaskeviciene, I.; Mangarov, A.; Mészner, Z.; Pokorn, M.; et al. Recommendations for tick-borne encephalitis vaccination from the Central European Vaccination Awareness Group (CEVAG). Hum. Vaccin. Immunother. 2013, 9, 362-374. [CrossRef] [PubMed]

59. Heinz, F.X.; Stiasny, K.; Holzmann, H.; Grgic-Vitek, M.; Kriz, B.; Essl, A.; Kundi, M. Vaccination and Tick-borne Encephalitis, Central Europe. Emerg. Infect. Dis. 2013, 19, 69-76. [CrossRef] [PubMed]

60. Zenz, W.; Pansi, H.; Zoehrer, B.; Mutz, I.; Holzmann, H.; Kraigher, A.; Berghold, A.; Spork, D. Tick-Borne Encephalitis in Children in Styria and Slovenia Between 1980 and 2003. Pediatr. Infect. Dis. J. 2005, 24, 892-896. [CrossRef]

61. Andersson, C.R.; Vene, S.; Insulander, M.; Lindquist, L.; Lundkvist, Å.; Günther, G. Vaccine failures after active immunisation against tick-borne encephalitis. Vaccine 2010, 28, 2827-2831. [CrossRef]

62. Hansson, K.E.; Rosdahl, A.; Insulander, M.; Vene, S.; Lindquist, L.; Gredmark-Russ, S.; Askling, H.H. Tick-borne Encephalitis Vaccine Failures: A 10-year Retrospective Study Supporting the Rationale for Adding an Extra Priming Dose in Individuals Starting at Age 50 Years. Clin. Infect. Dis. 2020, 70, 245-251. [CrossRef]

63. Lotrič-Furlan, S.; Bogovič, P.; Avšič-Županc, T.; Jelovšek, M.; Lusa, L.; Strle, F. Tick-borne encephalitis in patients vaccinated against this disease. J. Intern. Med. 2017, 282, 142-155. [CrossRef]

64. Bender, A.; Jäger, G.; Scheuerer, W.; Feddersen, B.; Kaiser, R.; Pfister, H.-W. Two severe cases of tick-borne encephalitis despite complete active vaccination-the significance of neutralizing antibodies. J. Neurol. 2004, 251, 353-354. [CrossRef] [PubMed]

65. Grgic-Vitek, M.; Avsic-Zupanc, T.; Klavs, I. Tick-borne encephalitis after vaccination: Vaccine failure or misdiagnosis. Vaccine 2010, 28, 7396-7400. [CrossRef] [PubMed]

66. Kleiter, I.; Jilg, W.; Bogdahn, U.; Steinbrecher, A. Delayed Humoral Immunity in a Patient with Severe Tick-borne Encephalitis after Complete Active Vaccination. Infection 2007, 35, 26-29. [CrossRef]

67. Sendi, P.; Hirzel, C.; Pfister, S.; Ackermann-Gäumann, R.; Grandgirard, D.; Hewer, E.; Nirkko, A.C. Fatal Outcome of European Tick-borne Encephalitis after Vaccine Failure. Front. Neurol. 2017, 8, 119. [CrossRef] [PubMed]

68. Kawasaki, T.; Kawai, T. Toll-like receptor signaling pathways. Front. Immunol. 2014, 5, 461. [CrossRef] [PubMed]

69. Lindqvist, R.; Upadhyay, A.; Överby, A.K. Tick-Borne Flaviviruses and the Type I Interferon Response. Viruses 2018, 10, 340. [CrossRef]

70. Carletti, T.; Zakaria, M.K.; Marcello, A. The host cell response to tick-borne encephalitis virus. Biochem. Biophys. Res. Commun. 2017, 492, 533-540. [CrossRef]

71. Dörrbecker, B.; Dobler, G.; Spiegel, M.; Hufert, F.T. Tick-borne encephalitis virus and the immune response of the mammalian host. Travel Med. Infect. Dis. 2010, 8, 213-222. [CrossRef]

72. Blom, K.; Braun, M.; Pakalniene, J.; Lunemann, S.; Enqvist, M.; Dailidyte, L.; Schaffer, M.; Lindquist, L.; Mickiene, A.; Michaëlsson, J.; et al. NK Cell Responses to Human Tick-Borne Encephalitis Virus Infection. J. Immunol. 2016, 197, 2762-2771. [CrossRef]

73. Best, S.M.; Morris, K.L.; Shannon, J.G.; Robertson, S.J.; Mitzel, D.N.; Park, G.S.; Boer, E.; Wolfinbarger, J.B.; Bloom, M.E. Inhibition of Interferon-Stimulated JAK-STAT Signaling by a Tick-Borne Flavivirus and Identification of NS5 as an Interferon Antagonist. J. Virol. 2005, 79, 12828-12839. [CrossRef]

74. Fares, M.; Cochet-Bernoin, M.; Gonzalez, G.; Montero-Menei, C.N.; Blanchet, O.; Benchoua, A.; Boissart, C.; Lecollinet, S.; Richardson, J.; Haddad, N.; et al. Pathological modeling of TBEV infection reveals differential innate immune responses in human neurons and astrocytes that correlate with their susceptibility to infection. J. Neuroinflammation 2020, 17, 76. [CrossRef]

75. Lieskovská, J.; Páleníková, J.; Langhansová, H.; Chmelař, J.; Kopecký, J. Saliva of Ixodes ricinus enhances TBE virus replication in dendritic cells by modulation of pro-survival Akt pathway. Virology 2018, 514, 98-105. [CrossRef] [PubMed]

76. Kotál, J.; Langhansová, H.; Lieskovská, J.; Andersen, J.F.; Francischetti, I.M.B.; Chavakis, T.; Kopecký, J.; Pedra, J.H.F.; Kotsyfakis, M.; Chmelař, J. Modulation of host immunity by tick saliva. J. Proteomics 2015, 128, 58-68. [CrossRef] [PubMed]

77. R̊̊žek, D.; Salát, J.; Palus, M.; Gritsun, T.S.; Gould, E.A.; Dyková, I.; Skallová, A.; Jelínek, J.; Kopecký, J.; Grubhoffer, L. CD8+ T-cells mediate immunopathology in tick-borne encephalitis. Virology 2009, 384, 1-6. [CrossRef] [PubMed] 
78. Pierson, T.C.; Diamond, M.S. Molecular mechanisms of antibody-mediated neutralisation of flavivirus infection. Expert Rev. Mol. Med. 2008, 10, e12. [CrossRef] [PubMed]

79. Hangartner, L.; Zinkernagel, R.M.; Hengartner, H. Antiviral antibody responses: The two extremes of a wide spectrum. Nat. Rev. Immunol. 2006, 6, 231-243. [CrossRef]

80. Pierson, T.C.; Fremont, D.H.; Kuhn, R.J.; Diamond, M.S. Structural Insights into the Mechanisms of Antibody-Mediated Neutralization of Flavivirus Infection: Implications for Vaccine Development. Cell Host Microbe 2008, 4, 229-238. [CrossRef]

81. Günther, G.; Haglund, M.; Lindquist, L.; Skoldenberg, B.; Forsgren, M. Intrathecal IgM, IgA and IgG antibody response in tick-borne encephalitis. Long-term follow-up related to clinical course and outcome. Clin. Diagn. Virol. 1997, 8, 17-29. [CrossRef]

82. Remoli, M.E.; Marchi, A.; Fortuna, C.; Benedetti, E.; Minelli, G.; Fiorentini, C.; Mel, R.; Venturi, G.; Ciufolini, M.G. Anti-tick-borne encephalitis (TBE) virus neutralizing antibodies dynamics in natural infections versus vaccination. Pathog. Dis. 2014, 73, 1-3. [CrossRef]

83. Kaiser, R.; Holzmann, H. Laboratory Findings in Tick-Borne Encephalitis-Correlation with Clinical Outcome. Infection 2000, 28, 78-84. [CrossRef]

84. Bradt, V.; Malafa, S.; von Braun, A.; Jarmer, J.; Tsouchnikas, G.; Medits, I.; Wanke, K.; Karrer, U.; Stiasny, K.; Heinz, F.X. Pre-existing yellow fever immunity impairs and modulates the antibody response to tick-borne encephalitis vaccination. npj Vaccines 2019, 4, 1-11. [CrossRef] [PubMed]

85. Beran, J.; Lattanzi, M.; Xie, F.; Moraschini, L.; Galgani, I. Second five-year follow-up after a booster vaccination against tick-borne encephalitis following different primary vaccination schedules demonstrates at least 10 years antibody persistence. Vaccine 2019, 37, 4623-4629. [CrossRef] [PubMed]

86. Weinberger, B.; Grubeck-Loebenstein, B. Vaccines for the elderly. Clin. Microbiol. Infect. 2012, 18, $100-108$. [CrossRef] [PubMed]

87. Stiasny, K.; Aberle, J.H.; Keller, M.; Grubeck-Loebenstein, B.; Heinz, F.X. Age Affects Quantity but not Quality of Antibody Responses after Vaccination with an Inactivated Flavivirus Vaccine against Tick-Borne Encephalitis. PLoS ONE 2012, 7, e34145. [CrossRef] [PubMed]

88. Kuivanen, S.; Hepojoki, J.; Vene, S.; Vaheri, A.; Vapalahti, O. Identification of linear human B-cell epitopes of tick-borne encephalitis virus. Virol. J. 2014, 11, 115. [CrossRef]

89. Kuhn, R.J.; Dowd, K.A.; Beth Post, C.; Pierson, T.C. Shake, rattle, and roll: Impact of the dynamics of flavivirus particles on their interactions with the host. Virology 2015, 479, 508-517. [CrossRef] [PubMed]

90. Nelson, S.; Jost, C.A.; Xu, Q.; Ess, J.; Martin, J.E.; Oliphant, T.; Whitehead, S.S.; Durbin, A.P.; Graham, B.S.; Diamond, M.S.; et al. Maturation of West Nile Virus Modulates Sensitivity to Antibody-Mediated Neutralization. PLoS Pathog. 2008, 4, e1000060. [CrossRef]

91. Fan, Y.-C.; Chiu, H.-C.; Chen, L.-K.; Chang, G.-J.J.; Chiou, S.-S. Formalin Inactivation of Japanese Encephalitis Virus Vaccine Alters the Antigenicity and Immunogenicity of a Neutralization Epitope in Envelope Protein Domain III. PLoS Negl. Trop. Dis. 2015, 9, e0004167. [CrossRef]

92. Zlatkovic, J.; Tsouchnikas, G.; Jarmer, J.; Koessl, C.; Stiasny, K.; Heinz, F.X. Aluminum Hydroxide Influences Not Only the Extent but Also the Fine Specificity and Functional Activity of Antibody Responses to Tick-Borne Encephalitis Virus in Mice. J. Virol. 2013, 87, 12187-12195. [CrossRef]

93. Jarmer, J.; Zlatkovic, J.; Tsouchnikas, G.; Vratskikh, O.; Strauss, J.; Aberle, J.H.; Chmelik, V.; Kundi, M.; Stiasny, K.; Heinz, F.X. Variation of the Specificity of the Human Antibody Responses after Tick-Borne Encephalitis Virus Infection and Vaccination. J. Virol. 2014, 88, 13845-13857. [CrossRef]

94. Albinsson, B.; Vene, S.; Rombo, L.; Blomberg, J.; Lundkvist, Å.; Rönnberg, B. Distinction between serological responses following tick-borne encephalitis virus (TBEV) infection vs vaccination, Sweden 2017. Eurosurveillance 2018, 23, 17-00838. [CrossRef] [PubMed]

95. Girl, P.; Bestehorn-Willmann, M.; Zange, S.; Borde, J.P.; Dobler, G.; von Buttlar, H. Tick-Borne Encephalitis Virus (TBEV): Nonstructural Protein 1 IgG Enzyme-Linked Immunosorbent Assay for Differentiating Infection versus Vaccination Antibody Responses. J. Clin. Microbiol. 2020, 58, e01783-19. [CrossRef] [PubMed]

96. Mora-Cárdenas, E.; Aloise, C.; Faoro, V.; Knap Gašper, N.; Korva, M.; Caracciolo, I.; D’Agaro, P.; Avšič-Županc, T.; Marcello, A. Comparative specificity and sensitivity of NS1-based serological assays for the detection of flavivirus immune response. PLoS Negl. Trop. Dis. 2020, 14, e0008039. [CrossRef] [PubMed] 
97. Salat, J.; Mikulasek, K.; Larralde, O.; Formanova, P.P.; Chrdle, A.; Haviernik, J.; Elsterova, J.; Teislerova, D.; Palus, M.; Eyer, L.; et al. Tick-Borne Encephalitis Virus Vaccines Contain Non-Structural Protein 1 Antigen and May Elicit NS1-Specific Antibody Responses in Vaccinated Individuals. Vaccines 2020, 8, 81. [CrossRef]

98. Aberle, J.H.; Schwaiger, J.; Aberle, S.W.; Stiasny, K.; Scheinost, O.; Kundi, M.; Chmelik, V.; Heinz, F.X. Human CD4+ T Helper Cell Responses after Tick-Borne Encephalitis Vaccination and Infection. PLoS ONE 2015, 10, e0140545. [CrossRef]

99. Schwaiger, J.; Aberle, J.H.; Stiasny, K.; Knapp, B.; Schreiner, W.; Fae, I.; Fischer, G.; Scheinost, O.; Chmelik, V.; Heinz, F.X. Specificities of Human CD4+ T Cell Responses to an Inactivated Flavivirus Vaccine and Infection: Correlation with Structure and Epitope Prediction. J. Virol. 2014, 88, 7828-7842. [CrossRef]

100. Varnaite, R.; Blom, K.; Lampen, M.H.; Vene, S.; Thunberg, S.; Lindquist, L.; Ljunggren, H.-G.; Rombo, L.; Askling, H.H.; Gredmark-Russ, S. Magnitude and Functional Profile of the Human CD4+ T Cell Response throughout Primary Immunization with Tick-Borne Encephalitis Virus Vaccine. J. Immunol. 2020, 204, 914-922. [CrossRef]

101. Volkova, T.D.; Koroev, D.O.; Titova, M.A.; Oboznaya, M.B.; Filatova, M.P.; Vorovich, M.F.; Ozherelkov, S.V.; Timofeev, A.V.; Volpina, O.M. Synthetic Fragments of the NS1 Protein of the Tick-Borne Encephalitis Eirus Exhibiting a Protective Effect. Russ. J. Bioorganic Chem. 2007, 33, 213-217. [CrossRef]

102. Aberle, J.H.; Stiasny, K.; Kundi, M.; Heinz, F.X. Mechanistic insights into the impairment of memory B cells and antibody production in the elderly. Age 2013, 35, 371-381. [CrossRef]

103. Lampen, M.H.; Uchtenhagen, H.; Blom, K.; Varnaitė, R.; Pakalniene, J.; Dailidyte, L.; Wälchli, S.; Lindquist, L.; Mickiene, A.; Michaëlsson, J.; et al. Breadth and Dynamics of HLA-A2-and HLA-B7-Restricted CD8+ T Cell Responses against Nonstructural Viral Proteins in Acute Human Tick-Borne Encephalitis Virus Infection. ImmunoHorizons 2018, 2, 172-184. [CrossRef]

104. Blom, K.; Braun, M.; Pakalniene, J.; Dailidyte, L.; Béziat, V.; Lampen, M.H.; Klingström, J.; Lagerqvist, N.; Kjerstadius, T.; Michaëlsson, J.; et al. Specificity and Dynamics of Effector and Memory CD8 T Cell Responses in Human Tick-Borne Encephalitis Virus Infection. PLoS Pathog. 2015, 11, e1004622. [CrossRef] [PubMed]

105. Jacobs, S.C. A novel recombinant adenovirus vector expressing a flavivirus non-structural protein protects against lethal flavivirus challenge. Clin. Sci. 1993, 85, 117-122. [CrossRef] [PubMed]

106. Jacobs, S.C.; Stephenson, J.R.; Wilkinson, G.W. High-Level Expression of the Tick-Borne Encephalitis Virus NS1 Protein by Using an Adenovirus-Based Vector: Protection Elicited in a Murine Model. J. Virol. 1992, 66, 2086-2095. [CrossRef] [PubMed]

107. Jacobs, S.C.; Stephenson, J.R.; Wilkinson, G.W.G. Protection elicited by a replication-defective adenovirus vector expressing the tick-borne encephalitis virus non-structural glycoprotein NS1. J. Gen. Virol. 1994, 75, 2399-2402. [CrossRef] [PubMed]

108. Volpina, O.M.; Volkova, T.D.; Koroev, D.O.; Ivanov, V.T.; Ozherelkov, S.V.; Khoretonenko, M.V.; Vorovitch, M.F.; Stephenson, J.R.; Timofeev, A.V. A synthetic peptide based on the NS1 non-structural protein of tick-borne encephalitis virus induces a protective immune response against fatal encephalitis in an experimental animal model. Virus Res. 2005, 112, 95-99. [CrossRef]

109. Rey, F.A.; Stiasny, K.; Vaney, M.; Dellarole, M.; Heinz, F.X. The bright and the dark side of human antibody responses to flaviviruses: Lessons for vaccine design. EMBO Rep. 2018, 19, 206-224. [CrossRef]

110. Pettersen, E.F.; Goddard, T.D.; Huang, C.C.; Couch, G.S.; Greenblatt, D.M.; Meng, E.C.; Ferrin, T.E. UCSF Chimera-A visualization system for exploratory research and analysis. J. Comput. Chem. 2004, 25, 1605-1612. [CrossRef]

111. Rey, F.A.; Heinz, F.X.; Mandl, C.; Kunz, C.; Harrison, S.C. The envelope glycoprotein from tick-borne encephalitis virus at 2 Å resolution. Nature 1995, 375, 291-298. [CrossRef]

112. Roehrig, J.T. Antigenic Structure of Flavivirus Proteins. Adv. Virus Res. 2003, 59, 141-175. [CrossRef]

113. Kiermayr, S.; Stiasny, K.; Heinz, F.X. Impact of Quaternary Organization on the Antigenic Structure of the Tick-Borne Encephalitis Virus Envelope Glycoprotein E. J. Virol. 2009, 83, 8482-8491. [CrossRef]

114. Lai, C.-Y.; Tsai, W.-Y.; Lin, S.-R.; Kao, C.-L.; Hu, H.-P.; King, C.-C.; Wu, H.-C.; Chang, G.-J.; Wang, W.-K. Antibodies to Envelope Glycoprotein of Dengue Virus during the Natural Course of Infection Are Predominantly Cross-Reactive and Recognize Epitopes Containing Highly Conserved Residues at the Fusion Loop of Domain II. J. Virol. 2008, 82, 6631-6643. [CrossRef] [PubMed] 
115. Oliphant, T.; Nybakken, G.E.; Engle, M.; Xu, Q.; Nelson, C.A.; Sukupolvi-Petty, S.; Marri, A.; Lachmi, B.-E.; Olshevsky, U.; Fremont, D.H.; et al. Antibody Recognition and Neutralization Determinants on Domains I and II of West Nile Virus Envelope Protein. J. Virol. 2006, 80, 12149-12159. [CrossRef] [PubMed]

116. Stiasny, K.; Kiermayr, S.; Holzmann, H.; Heinz, F.X. Cryptic Properties of a Cluster of Dominant Flavivirus Cross-Reactive Antigenic Sites. J. Virol. 2006, 80, 9557-9568. [CrossRef] [PubMed]

117. Chung, K.M.; Nybakken, G.E.; Thompson, B.S.; Engle, M.J.; Marri, A.; Fremont, D.H.; Diamond, M.S. Antibodies against West Nile Virus Nonstructural Protein NS1 Prevent Lethal Infection through Fc $\gamma$ Receptor-Dependent and -Independent Mechanisms. J. Virol. 2006, 80, 1340-1351. [CrossRef]

118. Falgout, B.; Bray, M.; Schlesinger, J.J.; Lai, C.-J. Immunization of Mice with Recombinant Vaccinia Virus Expressing Authentic Dengue Virus Nonstructural Protein NS1 Protects against Lethal Dengue Virus Encephalitis. J. Virol. 1990, 64, 4356-4363. [CrossRef]

119. Gould, E.A.; Buckley, A.; Barrett, A.D.T.; Cammack, N. Neutralizing (54K) and Non-neutralizing (54K and 48K) Monoclonal Antibodies against Structural and Non-structural Yellow Fever Virus Proteins Confer Immunity in Mice. J. Gen. Virol. 1986, 67, 591-595. [CrossRef]

120. Henchal, E.A.; Henchal, L.S.; Schlesinger, J.J. Synergistic Interactions of Anti-NS1 Monoclonal Antibodies Protect Passively Immunized Mice from Lethal Challenge with Dengue 2 Virus. J. Gen. Virol. 1988, 69, 2101-2107. [CrossRef]

121. Schlesinger, J.J.; Brandriss, M.W.; Cropp, C.B.; Monath, T.P. Protection against Yellow Fever in Monkeys by Immunization with Yellow Fever Virus Nonstructural Protein NS1. J. Virol. 1986, 60, 1153-1155. [CrossRef]

122. Schlesinger, J.J.; Brandriss, M.W.; Walsh, E.E. Protection of Mice against Dengue 2 Virus Encephalitis by Immunization with the Dengue 2 Virus Non-structural Glycoprotein NS1. J. Gen. Virol. 1987, 68, 853-857. [CrossRef]

123. Wan, S.-W.; Chen, P.-W.; Chen, C.-Y.; Lai, Y.-C.; Chu, Y.-T.; Hung, C.-Y.; Lee, H.; Wu, H.F.; Chuang, Y.-C.; Lin, J.; et al. Therapeutic Effects of Monoclonal Antibody against Dengue Virus NS1 in a STAT1 Knockout Mouse Model of Dengue Infection. J. Immunol. 2017, 199, 2834-2844. [CrossRef]

124. Kreil, T.R.; Maier, E.; Fraiss, S.; Eibl, M.M. Neutralizing Antibodies Protect against Lethal Flavivirus Challenge but Allow for the Development of Active Humoral Immunity to a Nonstructural Virus Protein. J. Virol. 1998, 72, 3076-3081. [CrossRef] [PubMed]

125. Kaufmann, B.M.; Summers, P.L.; Dubois, R.D.; Houston Cohen, W.; Gentry, M.K.; Timchack, R.L.; Burke, D.S.; Eckels, K.H. Monoclonal Antibodies for Dengue Virus prM Glycoprotein Protect Mice against Lethal Dengue Infection. Am. J. Trop. Med. Hyg. 1989, 41, 576-580. [CrossRef] [PubMed]

126. Bray, M.; Lai, C.-J. Dengue Virus Premembrane and Membrane Proteins Elicit a Protective Immune Response. Virology 1991, 185, 505-508. [CrossRef]

127. Beltramello, M.; Williams, K.L.; Simmons, C.P.; MacAgno, A.; Simonelli, L.; Quyen, N.T.H.; Sukupolvi-Petty, S.; Navarro-Sanchez, E.; Young, P.R.; De Silva, A.M.; et al. The Human Immune Response to Dengue Virus is Dominated by Highly Cross-Reactive Antibodies Endowed with Neutralizing and Enhancing Activity. Cell Host Microbe 2010, 8, 271-283. [CrossRef]

128. Dejnirattisai, W.; Jumnainsong, A.; Onsirisakul, N.; Fitton, P.; Vasanawathana, S.; Limpitikul, W.; Puttikhunt, C.; Edwards, C.; Duangchinda, T.; Supasa, S.; et al. Cross-Reacting Antibodies Enhance Dengue Virus Infection in Humans. Science 2010, 328, 745-748. [CrossRef]

129. Tsouchnikas, G.; Zlatkovic, J.; Jarmer, J.; Strauß, J.; Vratskikh, O.; Kundi, M.; Stiasny, K.; Heinz, F.X. Immunization with Immune Complexes Modulates the Fine Specificity of Antibody Responses to a Flavivirus Antigen. J. Virol. 2015, 89, 7970-7978. [CrossRef]

130. Chernokhaeva, L.L.; Rogova, Y.V.; Vorovitch, M.F.; Romanova, L.I.; Kozlovskaya, L.I.; Maikova, G.B.; Kholodilov, I.S.; Karganova, G.G. Protective immunity spectrum induced by immunization with a vaccine from the TBEV strain Sofjin. Vaccine 2016, 34, 2354-2361. [CrossRef]

131. Domnich, A.; Panatto, D.; Klementievna Arbuzova, E.; Signori, A.; Avio, U.; Gasparini, R.; Amicizia, D. Immunogenicity against Far Eastern and Siberian subtypes of tick-borne encephalitis (TBE) virus elicited by the currently available vaccines based on the European subtype: Systematic review and meta-analysis. Hum. Vaccin. Immunother. 2014, 10, 2819-2833. [CrossRef]

132. Fritz, R.; Orlinger, K.K.; Hofmeister, Y.; Janecki, K.; Traweger, A.; Perez-Burgos, L.; Barrett, P.N.; Kreil, T.R. Quantitative comparison of the cross-protection induced by tick-borne encephalitis virus vaccines based on European and Far Eastern virus subtypes. Vaccine 2012, 30, 1165-1169. [CrossRef] 
133. McAuley, A.J.; Sawatsky, B.; Ksiazek, T.; Torres, M.; Korva, M.; Lotrič-Furlan, S.; Avšič-Županc, T.; von Messling, V.; Holbrook, M.R.; Freiberg, A.N.; et al. Cross-neutralisation of viruses of the tick-borne encephalitis complex following tick-borne encephalitis vaccination and/or infection. npj Vaccines 2017, 2, 1-10. [CrossRef]

134. Morozova, O.V.; Bakhvalova, V.N.; Potapova, O.F.; Grishechkin, A.E.; Isaeva, E.I.; Aldarov, K.V.; Klinov, D.V.; Vorovich, M.F. Evaluation of immune response and protective effect of four vaccines against the tick-borne encephalitis virus. Vaccine 2014, 32, 3101-3106. [CrossRef] [PubMed]

135. Chernokhaeva, L.L.; Rogova, Y.V.; Kozlovskaya, L.I.; Romanova, L.I.; Osolodkin, D.I.; Vorovitch, M.F.; Karganova, G.G. Experimental Evaluation of the Protective Efficacy of Tick-Borne Encephalitis (TBE) Vaccines Based on European and Far-Eastern TBEV Strains in Mice and in Vitro. Front. Microbiol. 2018, 9, 1487. [CrossRef] [PubMed]

136. Beck, Y.; Fritz, R.; Orlinger, K.; Kiermayr, S.; Ilk, R.; Portsmouth, D.; Pöllabauer, E.-M.; Löw-Baselli, A.; Hessel, A.; Kölch, D.; et al. Molecular Basis of the Divergent Immunogenicity of Two Pediatric Tick-Borne Encephalitis Virus Vaccines. J. Virol. 2016, 90, 1964-1972. [CrossRef] [PubMed]

137. Chidumayo, N.N.; Yoshii, K.; Kariwa, H. Evaluation of the European tick-borne encephalitis vaccine against Omsk hemorrhagic fever virus. Microbiol. Immunol. 2014, 58, 112-118. [CrossRef]

138. Mansfield, K.L.; Horton, D.L.; Johnson, N.; Li, L.; Barrett, A.D.T.; Smith, D.J.; Galbraith, S.E.; Solomon, T.; Fooks, A.R. Flavivirus-induced antibody cross-reactivity. J. Gen. Virol. 2011, 92, 2821-2829. [CrossRef]

139. Schuller, E.; Klade, C.S.; Heinz, F.X.; Kollaritsch, H.; Rendi-Wagner, P.; Jilma, B.; Tauber, E. Effect of pre-existing anti-tick-borne encephalitis virus immunity on neutralising antibody response to the Vero cell-derived, inactivated Japanese encephalitis virus vaccine candidate IC51. Vaccine 2008, 26, 6151-6156. [CrossRef]

140. Koraka, P.; Zeller, H.; Niedrig, M.; Osterhaus, A.D.M.E.; Groen, J. Reactivity of serum samples from patients with a flavivirus infection measured by immunofluorescence assay and ELISA. Microbes Infect. 2002, 4, 1209-1215. [CrossRef]

141. Takada, A.; Kawaoka, Y. Antibody-dependent enhancement of viral infection: Molecular mechanisms and in vivo implications. Rev. Med. Virol. 2003, 13, 387-398. [CrossRef]

142. Haslwanter, D.; Blaas, D.; Heinz, F.X.; Stiasny, K. A novel mechanism of antibody-mediated enhancement of flavivirus infection. PLoS Pathog. 2017, 13, e1006643. [CrossRef]

143. St. John, A.L.; Rathore, A.P.S. Adaptive immune responses to primary and secondary dengue virus infections. Nat. Rev. Immunol. 2019, 19, 218-230. [CrossRef]

144. Wilken, L.; Rimmelzwaan, G.F. Adaptive Immunity to Dengue Virus: Slippery Slope or Solid Ground for Rational Vaccine Design? Pathogens 2020, 9, 470. [CrossRef] [PubMed]

145. Phillpotts, R.J.; Stephenson, J.R.; Porterfield, J.S. Antibody-dependent Enhancement of Tick-borne Encephalitis Virus Infectivity. J. Gen. Virol. 1985, 66, 1831-1837. [CrossRef] [PubMed]

146. Kopecký, J.; Grubhoffer, L.; Tomková, E. Interaction of tick-borne encephalitis virus with mouse peritoneal macrophages. The effect of antiviral antibody and lectin. Acta Virol. 1991, 35, 218-225. [PubMed]

147. Kreil, T.R.; Eibl, M.M. Pre-and Postexposure Protection by Passive Immunoglobulin but no Enhancement of Infection with a Flavivirus in a Mouse Model. J. Virol. 1997, 71, 2921-2927. [CrossRef] [PubMed]

148. Elsterova, J.; Palus, M.; Sirmarova, J.; Kopecky, J.; Niller, H.H.; Ruzek, D. Tick-borne encephalitis virus neutralization by high dose intravenous immunoglobulin. Ticks Tick-Borne Dis. 2017, 8, 253-258. [CrossRef] [PubMed]

149. Matveev, A.L.; Kozlova, I.V.; Stronin, O.V.; Khlusevich, Y.A.; Doroshchenko, E.K.; Baykov, I.K.; Lisak, O.V.; Emelyanova, L.A.; Suntsova, O.V.; Matveeva, V.A.; et al. Post-exposure administration of chimeric antibody protects mice against European, Siberian, and Far-Eastern subtypes of tick-borne encephalitis virus. PLoS ONE 2019, 14, e0215075. [CrossRef]

150. Duehr, J.; Lee, S.; Singh, G.; Foster, G.A.; Krysztof, D.; Stramer, S.L.; González, M.C.B.; Menichetti, E.; Geretschläger, R.; Gabriel, C.; et al. Tick-Borne Encephalitis Virus Vaccine-Induced Human Antibodies Mediate Negligible Enhancement of Zika Virus Infection In Vitro and in a Mouse Model. MSphere 2018, 3, e00011-18. [CrossRef]

151. Wieczorek, M.; Abualrous, E.T.; Sticht, J.; Álvaro-Benito, M.; Stolzenberg, S.; Noé, F.; Freund, C. Major Histocompatibility Complex (MHC) Class I and MHC Class II Proteins: Conformational Plasticity in Antigen Presentation. Front. Immunol. 2017, 8, 292. [CrossRef] 
152. Sant, A.J.; McMichael, A. Revealing the role of CD4+ T cells in viral immunity. J. Exp. Med. 2012, 209, 1391-1395. [CrossRef]

153. Elong Ngono, A.; Young, M.P.; Bunz, M.; Xu, Z.; Hattakam, S.; Vizcarra, E.; Regla-Nava, J.A.; Tang, W.W.; Yamabhai, M.; Wen, J.; et al. CD4+ T cells promote humoral immunity and viral control during Zika virus infection. PLoS Pathog. 2019, 15, e1007474. [CrossRef]

154. Sitati, E.M.; Diamond, M.S. CD4+ T-Cell Responses Are Required for Clearance of West Nile Virus from the Central Nervous System. J. Virol. 2006, 80, 12060-12069. [CrossRef] [PubMed]

155. Turtle, L.; Bali, T.; Buxton, G.; Chib, S.; Chan, S.; Soni, M.; Hussain, M.; Isenman, H.; Fadnis, P.; Venkataswamy, M.M.; et al. Human T cell responses to Japanese encephalitis virus in health and disease. J. Exp. Med. 2016, 213, 1331-1352. [CrossRef] [PubMed]

156. Koblischke, M.; Stiasny, K.; Aberle, S.W.; Malafa, S.; Tsouchnikas, G.; Schwaiger, J.; Kundi, M.; Heinz, F.X.; Aberle, J.H. Structural Influence on the Dominance of Virus-Specific CD4 T Cell Epitopes in Zika Virus Infection. Front. Immunol. 2018, 9, 1196. [CrossRef] [PubMed]

157. Brien, J.D.; Uhrlaub, J.L.; Nikolich-Žugich, J. West Nile Virus-Specific CD4 T Cells Exhibit Direct Antiviral Cytokine Secretion and Cytotoxicity and Are Sufficient for Antiviral Protection. J. Immunol. 2008, 181, 8568-8575. [CrossRef] [PubMed]

158. Kurane, I.; Meager, A.; Ennis, F.A. Dengue Virus-Specific Human T Cell Clones. Serotype Crossreactive Proliferation, Interferon $\gamma$ Production, and Cytotoxic Activity. J. Exp. Med. 1989, 170, 763-775. [CrossRef] [PubMed]

159. Liu, T.; Chambers, T.J. Yellow Fever Virus Encephalitis: Properties of the Brain-Associated T-Cell Response during Virus Clearance in Normal and Gamma Interferon-Deficient Mice and Requirement for CD4+ Lymphocytes. J. Virol. 2001, 75, 2107-2118. [CrossRef]

160. Mangada, M.M.; Rothman, A.L. Altered Cytokine Responses of Dengue-Specific CD4+ T Cells to Heterologous Serotypes. J. Immunol. 2005, 175, 2676-2683. [CrossRef]

161. Silva, M.L.; Martins, M.A.; Espírito-Santo, L.R.; Campi-Azevedo, A.C.; Silveira-Lemos, D.; Ribeiro, J.G.L.; Homma, A.; Kroon, E.G.; Teixeira-Carvalho, A.; Elói-Santos, S.M.; et al. Characterization of main cytokine sources from the innate and adaptive immune responses following primary 17DD yellow fever vaccination in adults. Vaccine 2011, 29, 583-592. [CrossRef]

162. Yauch, L.E.; Prestwood, T.R.; May, M.M.; Morar, M.M.; Zellweger, R.M.; Peters, B.; Sette, A.; Shresta, S. CD4+ T Cells Are Not Required for the Induction of Dengue Virus-Specific CD8+ T Cell or Antibody Responses but Contribute to Protection after Vaccination. J. Immunol. 2010, 185, 5405-5416. [CrossRef]

163. Xiang, J.; McLinden, J.H.; Rydze, R.A.; Chang, Q.; Kaufman, T.M.; Klinzman, D.; Stapleton, J.T. Viruses within the Flaviviridae Decrease CD4 Expression and Inhibit HIV Replication in Human CD4+ Cells. J. Immunol. 2009, 183, 7860-7869. [CrossRef]

164. Rathore, A.P.S.; St John, A.L. Cross-Reactive Immunity among Flaviviruses. Front. Immunol. 2020, 11, 334. [CrossRef] [PubMed]

165. Aihara, H.; Takasaki, T.; Matsutani, T.; Suzuki, R.; Kurane, I. Establishment and Characterization of Japanese Encephalitis Virus-Specific, Human CD4+ T-Cell Clones: Flavivirus Cross-Reactivity, Protein Recognition, and Cytotoxic Activity. J. Virol. 1998, 72, 8032-8036. [CrossRef] [PubMed]

166. Saron, W.A.A.; Rathore, A.P.S.; Ting, L.; Ooi, E.E.; Low, J.; Abraham, S.N.; St John, A.L. Flavivirus serocomplex cross-reactive immunity is protective by activating heterologous memory CD4 T cells. Sci. Adv. 2018, 4, eaar4297. [CrossRef] [PubMed]

167. Elong Ngono, A.; Shresta, S. Cross-Reactive T Cell Immunity to Dengue and Zika Viruses: New Insights Into Vaccine Development. Front. Immunol. 2019, 10, 1316. [CrossRef]

168. Gelpi, E.; Preusser, M.; Laggner, U.; Garzuly, F.; Holzmann, H.; Heinz, F.X.; Budka, H. Inflammatory response in human tick-borne encephalitis: Analysis of postmortem brain tissue. J. Neurovirol. 2006, 12, 322-327. [CrossRef]

169. Gelpi, E.; Preusser, M.; Garzuly, F.; Holzmann, H.; Heinz, F.X.; Budka, H. Visualization of Central European Tick-Borne Encephalitis Infection in Fatal Human Cases. J. Neuropathol. Exp. Neurol. 2005, 64, 506-512. [CrossRef]

170. Fujii, Y.; Hayasaka, D.; Kitaura, K.; Takasaki, T.; Suzuki, R.; Kurane, I. T-Cell Clones Expressing Different T-Cell Receptors Accumulate in the Brains of Dying and Surviving Mice After Peripheral Infection with Far Eastern Strain of Tick-Borne Encephalitis Virus. Viral Immunol. 2011, 24, 291-302. [CrossRef] 
171. Johnson, R.T.; Burke, D.S.; Elwell, M.; Leake, C.J.; Nisalak, A.; Hoke, C.H.; Lorsomrudee, W. Japanese Encephalitis: Immunocytochemical Studies of Viral Antigen and Inflammatory Cells in Fatal Cases. Ann. Neurol. 1985, 18, 567-573. [CrossRef]

172. Liu, Y.; Blanden, R.V.; Müllbacher, A. Identification of Cytolytic Lymphocytes in West Nile Virus-infected Murine Central Nervous System. J. Gen. Virol. 1989, 70, 565-573. [CrossRef]

173. Wang, Y.; Lobigs, M.; Lee, E.; Müllbacher, A. CD8+ T Cells Mediate Recovery and Immunopathology in West Nile Virus Encephalitis. J. Virol. 2003, 77, 13323-13334. [CrossRef]

174. Aberle, J.H.; Aberle, S.W.; Kofler, R.M.; Mandl, C.W. Humoral and Cellular Immune Response to RNA Immunization with Flavivirus Replicons Derived from Tick-Borne Encephalitis Virus. J. Virol. 2005, 79, 15107-15113. [CrossRef]

175. Gomez, I.; Marx, F.; Saurwein-Teissl, M.; Gould, E.A.; Grubeck-Loebenstein, B. Characterization of Tick-Borne Encephalitis Virus-Specific Human T Lymphocyte Responses by Stimulation with Structural TBEV Proteins Expressed in a Recombinant Baculovirus. Viral Immunol. 2003, 16, 407-414. [CrossRef] [PubMed]

176. Dobler, G.; Kaier, K.; Hehn, P.; Böhmer, M.M.; Kreusch, T.M.; Borde, J.P. Tick-borne encephalitis virus vaccination breakthrough infections in Germany-A retrospective analysis from 2001-2018. Clin. Microbiol. Infect. 2019. [CrossRef]

177. Rendi-Wagner, P.; Zent, O.; Jilg, W.; Plentz, A.; Beran, J.; Kollaritsch, H. Persistence of antibodies after vaccination against tick-borne encephalitis. Int. J. Med. Microbiol. 2006, 296, 202-207. [CrossRef]

178. Lotric-Furlan, S.; Avšič-Županc, T.; Strle, F. Tick-borne encephalitis after active immunization. Int. J. Med. Microbiol. 2008, 298, 309-313. [CrossRef]

179. Stiasny, K.; Holzmann, H.; Heinz, F.X. Characteristics of antibody responses in tick-borne encephalitis vaccination breakthroughs. Vaccine 2009, 27, 7021-7026. [CrossRef] [PubMed]

180. Garner-Spitzer, E.; Wagner, A.; Paulke-Korinek, M.; Kollaritsch, H.; Heinz, F.X.; Redlberger-Fritz, M.; Stiasny, K.; Fischer, G.F.; Kundi, M.; Wiedermann, U. Tick-Borne Encephalitis (TBE) and Hepatitis B Nonresponders Feature Different Immunologic Mechanisms in Response to TBE and Influenza Vaccination with Involvement of Regulatory T and B Cells and IL-10. J. Immunol. 2013, 191, 2426-2436. [CrossRef] [PubMed]

181. Heinz, F.X.; Allison, S.L.; Stiasny, K.; Schalich, J.; Holzmann, H.; Mandl, C.W.; Kunz, C. Recombinant and virion-derived soluble and particulate immunogens for vaccination against tick-borne encephalitis. Vaccine 1995, 13, 1636-1642. [CrossRef]

182. Aberle, J.H.; Aberle, S.W.; Allison, S.L.; Stiasny, K.; Ecker, M.; Mandl, C.W.; Berger, R.; Heinz, F.X. A DNA Immunization Model Study with Constructs Expressing the Tick-Borne Encephalitis Virus Envelope Protein E in Different Physical Forms. J. Immunol. 1999, 163, 6756-6761.

183. Slon Campos, J.L.; Poggianella, M.; Marchese, S.; Mossenta, M.; Rana, J.; Arnoldi, F.; Bestagno, M.; Burrone, O.R. DNA-immunisation with dengue virus E protein domains I/II, but not domain III, enhances Zika, West Nile and Yellow Fever virus infection. PLoS ONE 2017, 12, e0181734. [CrossRef]

184. Martina, B.E.E.; van den Doel, P.; Koraka, P.; van Amerongen, G.; Spohn, G.; Haagmans, B.L.; Provacia, L.B.V.; Osterhaus, A.D.M.E.; Rimmelzwaan, G.F. A Recombinant Influenza A Virus Expressing Domain III of West Nile Virus Induces Protective Immune Responses against Influenza and West Nile Virus. PLoS ONE 2011, 6, e18995. [CrossRef] [PubMed]

185. López-Camacho, C.; De Lorenzo, G.; Slon-Campos, J.L.; Dowall, S.; Abbink, P.; Larocca, R.A.; Kim, Y.C.; Poggianella, M.; Graham, V.; Findlay-Wilson, S.; et al. Immunogenicity and Efficacy of Zika Virus Envelope Domain III in DNA, Protein, and ChAdOx1 Adenoviral-Vectored Vaccines. Vaccines 2020, 8, 307. [CrossRef] [PubMed]

186. Wong, S.H.; Jassey, A.; Wang, J.Y.; Wang, W.-C.; Liu, C.-H.; Lin, L.-T. Virus-Like Particle Systems for Vaccine Development against Viruses in the Flaviviridae Family. Vaccines 2019, 7, 123. [CrossRef] [PubMed]

187. Allison, S.L.; Stadler, K.; Mandl, C.W.; Kunz, C.; Heinz, F.X. Synthesis and Secretion of Recombinant Tick-Borne Encephalitis Virus Protein E in Soluble and Particulate Form. J. Virol. 1995, 69, 5816-5820. [CrossRef] [PubMed]

188. Gehrke, R.; Ecker, M.; Aberle, S.W.; Allison, S.L.; Heinz, F.X.; Mandl, C.W. Incorporation of Tick-Borne Encephalitis Virus Replicons into Virus-Like Particles by a Packaging Cell Line. J. Virol. 2003, 77, 8924-8933. [CrossRef] 
189. Yun, S.-M.; Jeong, Y.E.; Wang, E.; Lee, Y.-J.; Han, M.G.; Park, C.; Lee, W.-J.; Choi, W. Cloning and Expression of Recombinant Tick-Borne Encephalitis Virus-like Particles in Pichia pastoris. Osong Public Heal. Res. Perspect. 2014, 5, 274-278. [CrossRef]

190. Schalich, J.; Allison, S.L.; Stiasny, K.; Mandl, C.W.; Kunz, C.; Heinz, F.X. Recombinant Subviral Particles from Tick-Borne Encephalitis Virus Are Fusogenic and Provide a Model System for Studying Flavivirus Envelope Glycoprotein Functions. J. Virol. 1996, 70, 4549-4557. [CrossRef]

191. Rodríguez-Limas, W.A.; Sekar, K.; Tyo, K.E.J. Virus-like particles: The future of microbial factories and cell-free systems as platforms for vaccine development. Curr. Opin. Biotechnol. 2013, 24, 1089-1093. [CrossRef]

192. Garg, H.; Mehmetoglu-Gurbuz, T.; Ruddy, G.M.; Joshi, A. Capsid containing virus like particle vaccine against Zika virus made from a stable cell line. Vaccine 2019, 37, 7123-7131. [CrossRef]

193. Schmaljohn, C.; VanderZanden, L.; Bray, M.; Custer, D.; Meyer, B.; Li, D.; Rossi, C.; Fuller, D.; Fuller, J.; Haynes, J.; et al. Naked DNA Vaccines Expressing the prM and E Genes of Russian Spring Summer Encephalitis Virus and Central European Encephalitis Virus Protect Mice from Homologous and Heterologous Challenge. J. Virol. 1997, 71, 9563-9569. [CrossRef]

194. Schmaljohn, C.; Custer, D.; VanderZanden, L.; Spik, K.; Rossi, C.; Bray, M. Evaluation of Tick-Borne Encephalitis DNA Vaccines in Monkeys. Virology 1999, 263, 166-174. [CrossRef]

195. Holzer, G.W.; Remp, G.; Antoine, G.; Pfleiderer, M.; Enzersberger, O.M.; Emsenhuber, W.; Hämmerle, T.; Gruber, F.; Urban, C.; Falkner, F.G.; et al. Highly Efficient Induction of Protective Immunity by a Vaccinia Virus Vector Defective in Late Gene Expression. J. Virol. 1999, 73, 4536-4542. [CrossRef] [PubMed]

196. Timofeev, A.V.; Ozherelkov, S.V.; Pronin, A.V.; Deeva, A.V.; Karganova, G.G.; Elbert, L.B.; Stephenson, J.R. Immunological basis for protection in a murine model of tick-borne encephalitis by a recombinant adenovirus carrying the gene encoding the NS1 non-structural protein. J. Gen. Virol. 1998, 79, 689-695. [CrossRef]

197. Khoretonenko, M.V.; Vorovitch, M.F.; Zakharova, L.G.; Pashvykina, G.V.; Ovsyannikova, N.V.; Stephenson, J.R.; Timofeev, A.V.; Altstein, A.D.; Shneider, A.M. Vaccinia virus recombinant expressing gene of tick-borne encephalitis virus non-structural NS1 protein elicits protective activity in mice. Immunol. Lett. 2003, 90, 161-163. [CrossRef] [PubMed]

198. Li, A.; Yu, J.; Lu, M.; Ma, Y.; Attia, Z.; Shan, C.; Xue, M.; Liang, X.; Craig, K.; Makadiya, N.; et al. A Zika virus vaccine expressing premembrane-envelope-NS1 polyprotein. Nat. Commun. 2018, 9, 3067. [CrossRef] [PubMed]

199. Mandl, C.W.; Aberle, J.H.; Aberle, S.W.; Holzmann, H.; Allison, S.L.; Heinz, F.X. In vitro-synthesized infectious RNA as an attenuated live vaccine in a flavivirus model. Nat. Med. 1998, 4, 1438-1440. [CrossRef] [PubMed]

200. Gritsun, T.S.; Lashkevich, V.A.; Gould, E.A. Tick-borne encephalitis. Antivir. Res. 2003, 57, $129-146$. [CrossRef]

201. VanBlargan, L.A.; Himansu, S.; Foreman, B.M.; Ebel, G.D.; Pierson, T.C.; Diamond, M.S. An mRNA Vaccine Protects Mice against Multiple Tick-Transmitted Flavivirus Infections. Cell Rep. 2018, 25, 3382-3392. [CrossRef]

202. Aberle, J.H.; Koblischke, M.; Stiasny, K. CD4 T cell responses to flaviviruses. J. Clin. Virol. 2018, 108, $126-131$. [CrossRef]

203. Panagioti, E.; Klenerman, P.; Lee, L.N.; van der Burg, S.H.; Arens, R. Features of Effective T Cell-Inducing Vaccines against Chronic Viral Infections. Front. Immunol. 2018, 9, 276. [CrossRef]

204. Volz, A.; Lim, S.; Kaserer, M.; Lülf, A.; Marr, L.; Jany, S.; Deeg, C.A.; Pijlman, G.P.; Koraka, P.; Osterhaus, A.D.M.E.; et al. Immunogenicity and protective efficacy of recombinant Modified Vaccinia virus Ankara candidate vaccines delivering West Nile virus envelope antigens. Vaccine 2016, 34, 1915-1926. [CrossRef] [PubMed]

205. Dai, S.; Zhang, T.; Zhang, Y.; Wang, H.; Deng, F. Zika Virus Baculovirus-Expressed Virus-Like Particles Induce Neutralizing Antibodies in Mice. Virol. Sin. 2018, 33, 213-226. [CrossRef] [PubMed]

206. Pardi, N.; Hogan, M.J.; Pelc, R.S.; Muramatsu, H.; Andersen, H.; DeMaso, C.R.; Dowd, K.A.; Sutherland, L.L.; Scearce, R.M.; Parks, R.; et al. Zika virus protection by a single low-dose nucleoside-modified mRNA vaccination. Nature 2017, 543, 248-251. [CrossRef] [PubMed] 
207. Omori-Urabe, Y.; Yoshii, K.; Ikawa-Yoshida, A.; Kariwa, H.; Takashima, I. Needle-free jet injection of DNA and protein vaccine of the Far-Eastern subtype of tick-borne encephalitis virus induces protective immunity in mice. Microbiol. Immunol. 2011, 55, 893-897. [CrossRef] [PubMed]

208. Suschak, J.J.; Williams, J.A.; Schmaljohn, C.S. Advancements in DNA vaccine vectors, non-mechanical delivery methods, and molecular adjuvants to increase immunogenicity. Hum. Vaccin. Immunother. 2017, 13, 2837-2848. [CrossRef] [PubMed]

209. Pardi, N.; Hogan, M.J.; Porter, F.W.; Weissman, D. mRNA vaccines-A new era in vaccinology. Nat. Rev. Drug Discov. 2018, 17, 261-279. [CrossRef]

210. Mastelic Gavillet, B.; Eberhardt, C.S.; Auderset, F.; Castellino, F.; Seubert, A.; Tregoning, J.S.; Lambert, P.-H.; de Gregorio, E.; Del Giudice, G.; Siegrist, C.-A. MF59 Mediates Its B Cell Adjuvanticity by Promoting T Follicular Helper Cells and Thus Germinal Center Responses in Adult and Early Life. J. Immunol. 2015, 194, 4836-4845. [CrossRef]

211. Dmitriev, I.P.; Khromykh, A.A.; Ignatyev, G.M.; Gainullina, M.N.; Ageenko, V.A.; Dryga, S.A.; Vorobyeva, M.S.; Sandakhchiev, L.S. Immunization with recombinant vaccinia viruses expressing structural and part of the nonstructural region of tick-borne encephalitis virus cDNA protect mice against lethal encephalitis. J. Biotechnol. 1996, 44, 97-103. [CrossRef]

212. Korenkov, D.; Isakova-Sivak, I.; Rudenko, L. Basics of CD8 T-cell immune responses after influenza infection and vaccination with inactivated or live attenuated influenza vaccine. Expert Rev. Vaccines 2018, 17, 977-987. [CrossRef]

213. Collins, N.D.; Barrett, A.D.T. Live Attenuated Yellow Fever 17D Vaccine: A Legacy Vaccine Still Controlling Outbreaks in Modern Day. Curr. Infect. Dis. Rep. 2017, 19, 14. [CrossRef]

214. De Fabritus, L.; Nougairède, A.; Aubry, F.; Gould, E.A.; De Lamballerie, X. Attenuation of Tick-Borne Encephalitis Virus Using Large-Scale Random Codon Re-encoding. PLoS Pathog. 2015, 11, e1004738. [CrossRef] [PubMed]

215. Gritsun, T.S.; Desai, A.; Gould, E.A. The degree of attenuation of tick-borne encephalitis virus depends on the cumulative effects of point mutations. J. Gen. Virol. 2001, 82, 1667-1675. [CrossRef] [PubMed]

216. Kofler, R.M.; Heinz, F.X.; Mandl, C.W. Capsid Protein C of Tick-Borne Encephalitis Virus Tolerates Large Internal Deletions and Is a Favorable Target for Attenuation of Virulence. J. Virol. 2002, 76, 3534-3543. [CrossRef] [PubMed]

217. Mandl, C.W.; Allison, S.L.; Holzmann, H.; Meixner, T.; Heinz, F.X. Attenuation of Tick-Borne Encephalitis Virus by Structure-Based Site-Specific Mutagenesis of a Putative Flavivirus Receptor Binding Site. J. Virol. 2000, 74, 9601-9609. [CrossRef] [PubMed]

218. Mandl, C.W.; Holzmann, H.; Meixner, T.; Rauscher, S.; Stadler, P.F.; Allison, S.L.; Heinz, F.X. Spontaneous and Engineered Deletions in the 3' Noncoding Region of Tick-Borne Encephalitis Virus: Construction of Highly Attenuated Mutants of a Flavivirus. J. Virol. 1998, 72, 2132-2140. [CrossRef]

219. Mandl, C.W.; Kroschewski, H.; Allison, S.L.; Kofler, R.; Holzmann, H.; Meixner, T.; Heinz, F.X. Adaptation of Tick-Borne Encephalitis Virus to BHK-21 Cells Results in the Formation of Multiple Heparan Sulfate Binding Sites in the Envelope Protein and Attenuation in Vivo. J. Virol. 2001, 75, 5627-5637. [CrossRef]

220. Kofler, R.M.; Leitner, A.; O’Riordain, G.; Heinz, F.X.; Mandl, C.W. Spontaneous Mutations Restore the Viability of Tick-Borne Encephalitis Virus Mutants with Large Deletions in Protein C. J. Virol. 2003, 77, 443-451. [CrossRef]

221. Guy, B.; Noriega, F.; Ochiai, R.L.; L'azou, M.; Delore, V.; Skipetrova, A.; Verdier, F.; Coudeville, L.; Savarino, S.; Jackson, N. A recombinant live attenuated tetravalent vaccine for the prevention of dengue. Expert Rev. Vaccines 2017, 16, 1-13. [CrossRef]

222. Appaiahgari, M.B.; Vrati, S. IMOJEVß: A Yellow fever virus-based novel Japanese encephalitis vaccine. Expert Rev. Vaccines 2010, 9, 1371-1384. [CrossRef]

223. Rumyantsev, A.A.; Goncalvez, A.P.; Giel-Moloney, M.; Catalan, J.; Liu, Y.; Gao, Q.; Almond, J.; Kleanthous, H.; Pugachev, K.V. Single-dose vaccine against tick-borne encephalitis. Proc. Natl. Acad. Sci. USA 2013, 110, 13103-13108. [CrossRef]

224. Wang, H.-J.; Li, X.-F.; Ye, Q.; Li, S.-H.; Deng, Y.-Q.; Zhao, H.; Xu, Y.-P.; Ma, J.; Qin, E.-D.; Qin, C.-F. Recombinant chimeric Japanese encephalitis virus/tick-borne encephalitis virus is attenuated and protective in mice. Vaccine 2014, 32, 949-956. [CrossRef] [PubMed] 
225. Pletnev, A.G.; Bray, M.; Huggins, J.; Lai, C.-J. Construction and characterization of chimeric tick-borne encephalitis/dengue type 4 viruses. Proc. Natl. Acad. Sci. USA 1992, 89, 10532-10536. [CrossRef] [PubMed]

226. Pletnev, A.G.; Bray, M.; Lai, C.-J. Chimeric Tick-Borne Encephalitis and Dengue Type 4 Viruses: Effects of Mutations on Neurovirulence in Mice. J. Virol. 1993, 67, 4956-4963. [CrossRef] [PubMed]

227. Pletnev, A.G.; Men, R. Attenuation of the Langat tick-borne flavivirus by chimerization with mosquito-borne flavivirus dengue type 4. Proc. Natl. Acad. Sci. USA 1998, 95, 1746-1751. [CrossRef] [PubMed]

228. Heiss, B.L.; Maximova, O.A.; Pletnev, A.G. Insertion of MicroRNA Targets into the Flavivirus Genome Alters Its Highly Neurovirulent Phenotype. J. Virol. 2011, 85, 1464-1472. [CrossRef]

229. Heiss, B.L.; Maximova, O.A.; Thach, D.C.; Speicher, J.M.; Pletnev, A.G. MicroRNA Targeting of Neurotropic Flavivirus: Effective Control of Virus Escape and Reversion to Neurovirulent Phenotype. J. Virol. 2012, 86, 5647-5659. [CrossRef]

230. Teterina, N.L.; Liu, G.; Maximova, O.A.; Pletnev, A.G. Silencing of neurotropic flavivirus replication in the central nervous system by combining multiple microRNA target insertions in two distinct viral genome regions. Virology 2014, 456, 247-258. [CrossRef]

231. Tsetsarkin, K.A.; Maximova, O.A.; Liu, G.; Kenney, H.; Teterina, N.L.; Pletnev, A.G. Stable and Highly Immunogenic MicroRNA-Targeted Single-Dose Live Attenuated Vaccine Candidate against Tick-Borne Encephalitis Constructed Using Genetic Backbone of Langat Virus. MBio 2019, 10, e02904-18. [CrossRef]

232. Engel, A.R.; Rumyantsev, A.A.; Maximova, O.A.; Speicher, J.M.; Heiss, B.; Murphy, B.R.; Pletnev, A.G. The neurovirulence and neuroinvasiveness of chimeric tick-borne encephalitis/dengue virus can be attenuated by introducing defined mutations into the envelope and NS5 protein genes and the 3 ' non-coding region of the genome. Virology 2010, 405, 243-252. [CrossRef]

233. Rumyantsev, A.A.; Chanock, R.M.; Murphy, B.R.; Pletnev, A.G. Comparison of live and inactivated tick-borne encephalitis virus vaccines for safety, immunogenicity and efficacy in rhesus monkeys. Vaccine 2006, 24, 133-143. [CrossRef]

234. Maximova, O.A.; Ward, J.M.; Asher, D.M.; Claire, M.S.; Finneyfrock, B.W.; Speicher, J.M.; Murphy, B.R.; Pletnev, A.G. Comparative Neuropathogenesis and Neurovirulence of Attenuated Flaviviruses in Nonhuman Primates. J. Virol. 2008, 82, 5255-5268. [CrossRef] [PubMed]

235. Pletnev, A.G.; Bray, M.; Hanley, K.A.; Speicher, J.; Elkins, R. Tick-Borne Langat/Mosquito-Borne Dengue Favivirus Chimera, a Candidate Live Attenuated Vaccine for Protection against Disease Caused by Members of the Tick-Borne Encephalitis Virus Complex: Evaluation in Rhesus Monkeys and in Mosquitos. J. Virol. 2001, 75, 8259-8267. [CrossRef] [PubMed]

236. Pletnev, A.G.; Karganova, G.G.; Dzhivanyan, T.I.; Lashkevich, V.A.; Bray, M. Chimeric Langat/Dengue Viruses Protect Mice from Heterologous Challenge with the Highly Virulent Strains of Tick-Borne Encephalitis Virus. Virology 2000, 274, 26-31. [CrossRef] [PubMed]

237. Wright, P.F.; Ankrah, S.; Henderson, S.E.; Durbin, A.P.; Speicher, J.; Whitehead, S.S.; Murphy, B.R.; Pletnev, A.G. Evaluation of the Langat/dengue 4 chimeric virus as a live attenuated tick-borne encephalitis vaccine for safety and immunogenicity in healthy adult volunteers. Vaccine 2008, 26, 882-890. [CrossRef] [PubMed]

238. Grifoni, A.; Voic, H.; Dhanda, S.K.; Kidd, C.K.; Brien, J.D.; Buus, S.; Stryhn, A.; Durbin, A.P.; Whitehead, S.; Diehl, S.A.; et al. T Cell Responses Induced by Attenuated Flavivirus Vaccination Are Specific and Show Limited Cross-Reactivity with Other Flavivirus Species. J. Virol. 2020, 94. [CrossRef]

239. Kofler, R.M.; Aberle, J.H.; Aberle, S.W.; Allison, S.L.; Heinz, F.X.; Mandl, C.W. Mimicking live flavivirus immunization with a noninfectious RNA vaccine. Proc. Natl. Acad. Sci. USA 2004, 101, 1951-1956. [CrossRef]

240. Mok, D.Z.L.; Chan, K.R. The Effects of Pre-Existing Antibodies on Live-Attenuated Viral Vaccines. Viruses 2020, 12, 520. [CrossRef]

241. Woodland, D.L. Jump-starting the immune system: Prime-boosting comes of age. Trends Immunol. 2004, 25, 98-104. [CrossRef]

242. Kardani, K.; Bolhassani, A.; Shahbazi, S. Prime-boost vaccine strategy against viral infections: Mechanisms and benefits. Vaccine 2016, 34, 413-423. [CrossRef]

243. Guimarães-Walker, A.; Mackie, N.; McCormack, S.; Hanke, T.; Schmidt, C.; Gilmour, J.; Barin, B.; McMichael, A.; Weber, J.; Legg, K.; et al. Lessons from IAVI-006, a Phase I clinical trial to evaluate the safety and immunogenicity of the pTHr.HIVA DNA and MVA.HIVA vaccines in a prime-boost strategy to induce HIV-1 specific T-cell responses in healthy volunteers. Vaccine 2008, 26, 6671-6677. [CrossRef] 
244. Churchyard, G.J.; Morgan, C.; Adams, E.; Hural, J.; Graham, B.S.; Moodie, Z.; Grove, D.; Gray, G.; Bekker, L.-G.; McElrath, M.J.; et al. A Phase IIA Randomized Clinical Trial of a Multiclade HIV-1 DNA Prime Followed by a Multiclade rAd5 HIV-1 Vaccine Boost in Healthy Adults (HVTN204). PLoS ONE 2011, 6, e21225. [CrossRef] [PubMed]

245. Jaoko, W.; Karita, E.; Kayitenkore, K.; Omosa-Manyonyi, G.; Allen, S.; Than, S.; Adams, E.M.; Graham, B.S.; Koup, R.A.; Bailer, R.T.; et al. Safety and Immunogenicity Study of Multiclade HIV-1 Adenoviral Vector Vaccine Alone or as Boost following a Multiclade HIV-1 DNA Vaccine in Africa. PLoS ONE 2010, 5, e12873. [CrossRef] [PubMed]

246. Aleshin, S.E.; Timofeev, A.V.; Khoretonenko, M.V.; Zakharova, L.G.; Pashvykina, G.V.; Stephenson, J.R.; Shneider, A.M.; Altstein, A.D. Combined prime-boost vaccination against tick-borne encephalitis (TBE) using a recombinant vaccinia virus and a bacterial plasmid both expressing TBE virus non-structural NS1 protein. BMC Microbiol. 2005, 5, 45. [CrossRef] [PubMed]

(C) 2020 by the authors. Licensee MDPI, Basel, Switzerland. This article is an open access article distributed under the terms and conditions of the Creative Commons Attribution (CC BY) license (http://creativecommons.org/licenses/by/4.0/). 